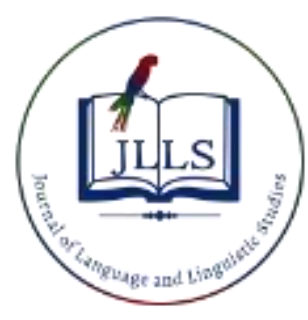

Available online at www.jlls.org

JOURNAL OF LANGUAGE AND LINGUISTIC STUDIES

ISSN: $1305-578 \mathrm{X}$

Journal of Language and Linguistic Studies, 16(1), 185-212; 2020

\title{
Analysis of problems encountered by instructors teaching Turkish as a foreign language to Syrian children and their opinions on their participation in the certification program for teaching Turkish as a foreign language
}

\begin{abstract}
Ufuk Özkale ${ }^{\mathrm{a}} 1$ (D), Tuğba Yanpar Yelken ${ }^{\mathrm{b}}$
${ }^{a}$ Tece Primary School, Mersin, Turkey

${ }^{b}$ Mersin University, Mersin, Turkey

\section{APA Citation:}

Özkale, U., \& Yanpar Yelken, T. (2020). Analysis of problems encountered by instructors teaching Turkish as a foreign language to Syrian children and their opinions on their participation in the certification program for teaching Turkish as a foreign language. Journal of Language and Linguistic Studies, 16(1), 185-212. Doi: 10.17263/jlls.712698

Submission Date:27/07/2019

Acceptance Date:06/11/2019
\end{abstract}

\begin{abstract}
This study seeks to determine the problems faced by the Turkish instructors serving in the primary education institutions and camps within the framework of the project PICTES in teaching Turkish as a foreign language to Syrian students and to provide insights into their opinions on their participation in the certification program for teaching Turkish as a foreign language created by Turkish Language Teaching, Research and Application Centre (TÖMER). Following a qualitative research model, this case study employs purposive sampling and there are 25 Turkish instructors serving in the city of Mersin and Adana in the sample of the study. The data are collected through personal information forms and interview forms. The data are analyzed by means of content analysis, using QDA (Qualitative Data Analysis) Miner Lite program. The analysis yields 14 themes and 37 codes grouped under these 14 themes. The results of this study are mostly congruent with previous research in the literature; the study concludes that most of the instructors do not benefit from instructional technologies and that the certification program created by TÖMER is not useful at the desired level in helping instructors use teaching methods and techniques.
\end{abstract}

(C) 2020 JLLS and the Authors - Published by JLLS.

Keywords: Teaching Turkish as a foreign language; Syrian children; instructional technologies; Turkish language teaching, research and application centre; promoting integration of Syrian children into the Turkish education system (pictes)

\section{Introduction}

Over the past years, many people of foreign origin have entered to Turkey due to the problems occurring in its neighboring countries, particularly the countries in its southeastern border. The majority of these people are Syrian citizens. As of December 20, 2018, the number of Syrian citizens who benefit from temporary protection in Turkey is 3,618.624 (Republic of Turkey Ministry of Interior Directorate

\footnotetext{
${ }^{1}$ Corresponding author. Tel.: $+0-000-0000000$

E-mail address: ozkaleufuk@gmail.com
} 
General of Migration Management, 2018). Almost 3.9 million refugees, most of whom are Syrian, are registered in Turkey; about 1.74 millions of them are children, including 1.6 million Syrian children (https://www.unicefturk.org). Education plays a fundamental role in helping Syrian children adapt to Turkey. Thus, many projects are being developed for the education of Syrian children. The first of these projects is "Teaching Turkish to Syrian Guest Students Project" in the refugee camps (Büyükikiz \& Çangal, 2016). With the new wave of refugees, the number of Syrian children of school age has increased, which entails the development of a more comprehensive project. In fact, the PICTES project aiming at promoting the successful integration of Syrian students into the Turkish education system began on October 3, 2016.

PICTES stand for Promoting Integration of Syrian Children into the Turkish Education System. The project Promoting Integration of Syrian Children into the Turkish Education System is aimed at supporting the efforts of the Turkish Ministry of National Education (MEB) for the integration of Syrian children into the Turkish Education System within the framework of the Financial Facilities for Refugees in Turkey (FRIT) agreement signed between the Turkish Ministry of National Education (MEB) and the EU Delegation to Turkey (https://pictes.meb.gov.tr/iz-leme). This project seeks to ensure that the Syrian refugees can have access to education in Turkey. It is notable that the main activity area in the project is teaching Turkish language, since knowledge of Turkish is critical for the integration of Syrian children into the Turkish Education System. In the state schools affiliated to the Turkish Ministry of National Education, the medium of instruction is Turkish. Thus, any student who does not speak Turkish is not expected to succeed in neither a mathematics course nor other courses.

The teachers who have been assigned (on a contractual basis) to teach Turkish to Syrian refugee children are the graduates of the department of Turkish teaching, Turkish language and literature, and classroom teaching (Eyüp, Arslan \& Cevher, 2017). These teachers perform Turkish teaching in the public schools affiliated with MEB, in Temporary Education Centers (GEMs) and in the refugee camps. GEMs are gradually being phased out and the students registered to these GEMs continue their education in primary education schools.

In this regard, it is important to train the Turkish instructors involved in this project on how to teach Turkish as a foreign language to deliver a more effective service in teaching. To this end, the Turkish Language Teaching, Research and Application Centre (TÖMER) created "the Certification Program for Teaching Turkish as a Foreign Language" for these teachers. TÖMERs were established in the recognition that teaching Turkish to foreigners is a specialty on its own. In 1984, TÖMER of Ankara University, affiliated with Ankara University Rectorate, was founded for the purposes of teaching Turkish to foreigners and some of the leading language and culture institutions such as the British Council, Goethe Institute, Cervantes and Alliance Française acted as models for the constitution of the Center. In later years, TÖMER of Gazi University (1994) and TÖMERs of Bolu İzzet Baysal University and Ege University were set up. New branches are still being opened in different universities (Yüce, 2005).

In general, the fields of activity of TÖMERs are as follows:

- To teach foreigners from Related Communities who have settled in Turkey to continue their graduate education in Turkey and are interested in learning Turkey Turkish,

- To teach Turkish dialects other than Turkey Turkish and to conduct research and analyses regarding these dialects,

- To carry out activities aimed at teaching Turkish both abroad and at home, and promoting Turkish culture, 
- To perform activities in areas of teaching, instruction, research, application and advertising in cooperation with the relevant ministries within the framework of the bilateral agreements signed by the Republic of Turkey,

- To design and implement training programs for the instructors assigned to teach Turkish at home and abroad,

- To develop native language teaching methods in cooperation with other institutions of interest,

- To organize short-term courses for Turkish children living abroad (Yüce, 2005).

In broad terms, language teaching, particularly foreign language teaching, is intended to develop "the four basic language skills", as recognized all around the world. Mehmet Hadi Benhûr (2006) emphasizes that the purpose of teaching Turkish to foreigners is to develop the four basic language skills (listening, speaking, reading and writing).

The Common European Framework of Reference for Languages (CEFR) was developed to provide a common basis for different language teaching systems and language skills around the world and to help individuals using the language being learned to communicate with others. The Framework defines levels of proficiency which allow learners' progress to be measured at each stage of learning and on a life-long basis (2001, cited in Büyükikiz \& Hasırc1, 2013). In general, the levels of proficiency in foreign language teaching can be categorized into three broad levels: basic, independent and proficient, as in the Common European Framework of Reference for Languages. These levels of proficiency are divided into three main areas as A, B and C to establish a common basis for all European languages. The learning outcomes that individuals are expected to gain in each level of proficiency for all language skills are elaborated in the Framework. The objective of the European Council in this Framework is to assess the proficiency of individuals in the language they study for the areas of reading, writing, speaking and listening according to the specified standards. Thanks to the description of these levels, the individuals who are involved in learning a foreign language can identify where they are in the learning process and find out what else they need to learn to achieve their goals. Further, language instructors can also determine if they have reached their goals or not and plan what they will teach and how. Table 1 presents the description of the levels of language proficiency.

Table 1. Levels of language proficiency

\begin{tabular}{|l|l|l|}
\hline C2 & $\begin{array}{c}\text { Can understand with ease virtually everything heard or read. Can } \\
\text { summaries information from different spoken and written sources, } \\
\text { reconstructing arguments and accounts in a coherent presentation. Can express } \\
\text { him/herself spontaneously, very fluently and precisely, differentiating finer } \\
\text { shades of Proficient meaning even in more complex situations. }\end{array}$ \\
\cline { 2 - 3 } & C1 & $\begin{array}{l}\text { Can understand a wide range of demanding, longer texts, and recognize } \\
\text { implicit meaning. Can express him/herself fluently and spontaneously without } \\
\text { much obvious searching for expressions. Can use language flexibly and } \\
\text { effectively for social, academic and professional purposes. Can produce clear, } \\
\text { well-structured, detailed text on complex subjects, showing controlled use of } \\
\text { organizational patterns, connectors and cohesive devices. }\end{array}$ \\
\hline
\end{tabular}




\section{Continued Table 1}

\begin{tabular}{|c|c|c|}
\hline \multirow[b]{2}{*}{ 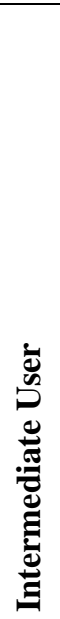 } & B2 & $\begin{array}{l}\text { Can understand the main ideas of complex text on both concrete and } \\
\text { abstract topics, including technical discussions in his/her field of } \\
\text { specialization. Can interact with a degree of fluency and spontaneity that } \\
\text { makes regular interaction with native speakers quite possible without strain } \\
\text { for either party. Can produce clear, detailed text on a wide range of subjects } \\
\text { and explain a viewpoint on a topical issue giving the advantages and } \\
\text { Independent disadvantages of various options. }\end{array}$ \\
\hline & B1 & $\begin{array}{l}\text { Can understand the main points of clear standard input on familiar matters } \\
\text { regularly encountered in work, school, leisure, etc. Can deal with most } \\
\text { situations likely to arise whilst travelling in an area where the language is } \\
\text { spoken. Can produce simple connected text on topics which are familiar or of } \\
\text { personal interest. Can describe experiences and events, dreams, hopes and } \\
\text { ambitions and briefly give reasons and explanations for opinions and plans. }\end{array}$ \\
\hline \multirow[b]{2}{*}{ 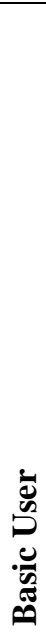 } & A2 & $\begin{array}{l}\text { Can understand sentences and frequently used expressions related to areas } \\
\text { of most immediate relevance (e.g. very basic personal and family information, } \\
\text { shopping, local geography, employment). Can communicate in simple and } \\
\text { routine tasks requiring a simple and direct exchange of information on } \\
\text { familiar and routine matters. Can describe in simple terms aspects of his/her } \\
\text { background, immediate environment and matters in areas of immediate need. }\end{array}$ \\
\hline & A1 & $\begin{array}{l}\text { Can understand and use familiar everyday expressions and very basic } \\
\text { phrases aimed at the satisfaction of needs of a concrete type. Can introduce } \\
\text { him/herself and others and can ask and answer questions about personal } \\
\text { details such as where he/she lives, people he/she knows and things he/she has. } \\
\text { Can interact in a simple way provided the other person talks slowly and clearly } \\
\text { and is prepared to help. }\end{array}$ \\
\hline
\end{tabular}

(Büyükikiz \& Hasırc1, 2013).

Turkish instructors are also expected to perform their teaching by considering the levels specified in Table 1.

This study aims to determine the problems encountered by Turkish instructors assigned in the project PICTES while teaching Turkish to Syrian children as a foreign language and to offer suggestions. Moreover, it seeks to provide insights into the opinions of Turkish instructors participating in the Certification Program for Teaching Turkish as a Foreign Language created by TÖMER.

\subsection{Research questions}

What are the problems encountered by Turkish instructors assigned in the project PICTES while teaching Turkish to Syrian children as a foreign language and the opinions of Turkish instructors on their participation in the Certification Program for Teaching Turkish as a Foreign Language?

\subsection{Sub-problems}

1. What are the problems faced by Turkish instructors regarding the four basic language skills (Reading, Writing, Listening, Speaking) in teaching Turkish to Syrian children? 
2. In teaching Turkish as a foreign language to Syrian children, what are the problems faced by Turkish instructors regarding

2.1. the administration in the institution they work at

2.2. the teachers or other Turkish instructors in the institution they work at

2.3. the students in the institution

2.4. the parents of the students

2.5. the learning environment?

3. To what extent do the Turkish instructors utilize instructional technologies in teaching Turkish to Syrian children?

4. What opinions do Turkish instructors have about the extent to which the certification program for teaching Turkish as a foreign language they participated is useful in teaching Turkish to

4.1. determine the outcomes,

4.2. present and organize the content,

4.3. use teaching methods and techniques,

4.4. measure and evaluate students?

\section{Method}

This is a case study following a qualitative research model. There are three qualitative approaches most commonly used for a case study: exploratory, descriptive and explanatory (Akar, 2017). Also, Yin (2014) argues that a case study can essentially include a single case or multiple cases. This study follows a multi-layered analysis design based on an explanatory and a single case study. McMillan (2000, cite in Büyüköztürk et al., 2014 ) case studies are defined as a method to analyze one or more events, settings, programs, social groups or other bounded systems in detail.

According to Yin, a case study is an empirical inquiry that investigates a contemporary phenomenon within its real-life context; when the boundaries between phenomenon and context are not clearly evident; and in which multiple sources of evidence are used (1984, cited in Yıldırım \& Şimşek, 2013). Further, case studies can be described as a research method based on the "why" and "how" questions to allow for the profound analysis of a phenomenon or an event that cannot be controlled by the researcher. In this study is the problems faced by the Turkish instructors teaching Turkish to Syrian children as a foreign language and the opinions they have regarding their participation in the Certification Program for Teaching Turkish as a Foreign Language. In this regard, the Turkish instructors at the primary education institutions in the city of Mersin and those at the refugee camps in the city of Adana were selected for a single case study in the same context and a multi-level analysis was performed and presented in the form of a report.

This study follows the model created by Yıldırım \& Şimşek (2013) by benefiting from Yin's (1984) model. Thus, the case study of this research paper is based on the following steps: 


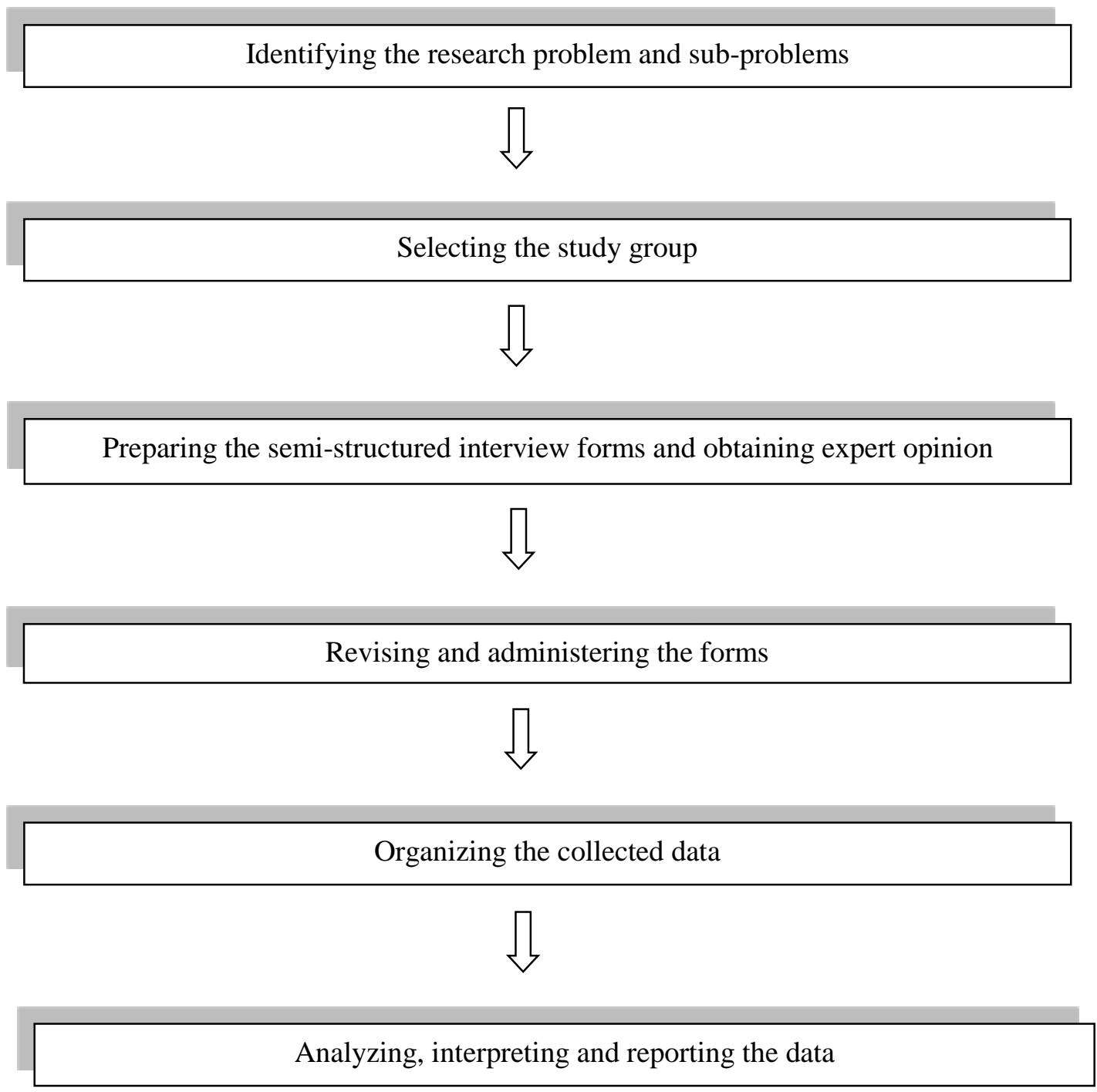

Figure 1. Research steps

\subsection{Sample / Participants}

The participants are the Turkish instructors serving in the city of Adana and Mersin for the project PICTES. The study follows a purposive sampling, which allows for the selection of items in such manner that they are rich in information and the detailed analysis of these items. Purposive sampling is used to study one or more cases that meet certain criteria or have some characteristics (Büyüköztürk et al., 2014). The criterion of this study is the Turkish Instructors serving within the framework of the project PICTES. The number of participants was limited according to the point of data saturation. Researchers with a sample of a certain size reach a point that they sample the same data. This point is defined as "data saturation" in data sampling. According to Glaser and Strauss a researcher, reaching to the point of data saturation, where the findings regarding the research problem are explicit enough, may realize that new data will not lead to more information or opinion (1967, cited in Yıldırım \& Şimşek, 2013). A total of 25 people participated in the study $(68.00 \%$ is female; average age is $\bar{X}=26 ; 32.00 \%$ is male; average age is participants $=28.38$ ). Of the participants, 21 are classroom teachers; 3 are Turkish teachers and the subject matter of one of them is Turkish language and literature. In the study, the participants are identified as $\mathrm{I}_{1}, \mathrm{I}_{2}, \mathrm{I}_{3}$. Table 2 shows the distribution of the participants in terms of gender and subject matter. 
Table 2. Distribution of participants in terms of gender and subject matter

\begin{tabular}{ccccc} 
& $\begin{array}{c}\text { Classroom } \\
\text { Teaching }\end{array}$ & $\begin{array}{c}\text { Turkish } \\
\text { Teaching }\end{array}$ & $\begin{array}{c}\text { Turkish } \\
\text { Language and } \\
\text { Literature }\end{array}$ & Total \\
\cline { 2 - 5 } & $\mathbf{f}$ & $\mathbf{f}$ & $\mathbf{f}$ & $\mathbf{f}$ \\
Female & 15 & $\mathbf{\%}$ & $\mathbf{\%}$ & $\mathbf{\%}$ \\
& 60.00 & 1 & 1 & 17 \\
Male & 6 & 4.00 & 4.00 & 68.00 \\
& 24.00 & 2 & 0 & 8 \\
Total & 21 & 3 & 0 & 32.00 \\
& 84.00 & 12.00 & 4.00 & 25 \\
& & & & 100.00 \\
\hline
\end{tabular}

Table 3 shows the distribution of the participants in terms of years of experience and place of duty.

Table 3. Distribution of subject matters of participants in terms of years of experience and place of duty

\begin{tabular}{|c|c|c|c|c|}
\hline Subject matter & Years of Experience & Participants & \multicolumn{2}{|c|}{ Place of Duty } \\
\hline & & $\begin{array}{c}\mathrm{I}_{1,} \mathrm{I}_{2}, \mathrm{I}_{5}, \mathrm{I}_{6} \mathrm{I}_{7}, \mathrm{I}_{9}, \mathrm{I}_{10}, \mathrm{I}_{11}, \\
\quad \mathrm{I}_{12}, \mathrm{I}_{13}, \mathrm{I}_{14}, \mathrm{I}_{15}, \mathrm{I}_{16}\end{array}$ & $\begin{array}{l}\text { Primary } \\
\text { institutions }\end{array}$ & education \\
\hline Classroom Teaching & $\begin{array}{c}\text { Between } 1 \text { year and } 2 \\
\text { years }\end{array}$ & $\begin{array}{c}\mathrm{I}_{17}, \mathrm{I}_{18}, \mathrm{I}_{19}, \mathrm{I}_{20}, \mathrm{I}_{21}, \mathrm{I}_{22}, \mathrm{I}_{23}, \\
\mathrm{I}_{25}\end{array}$ & Camp & \\
\hline Turkish Teaching & $\begin{array}{c}\text { Between } 1.5 \text { years and } 2.5 \\
\text { years }\end{array}$ & $\mathrm{I}_{3}, \mathrm{I}_{4}, \mathrm{I}_{8}$ & \multirow{2}{*}{$\begin{array}{l}\text { Primary } \\
\text { institutions } \\
\text { Camp }\end{array}$} & \multirow[t]{2}{*}{ education } \\
\hline $\begin{array}{c}\text { Turkish Language and } \\
\text { Literature }\end{array}$ & 2 years & $\mathrm{I}_{24}$ & & \\
\hline
\end{tabular}

\subsection{Data collection procedures}

The data were collected through the personal information forms and interview forms. The interview forms developed by means of literature review were revised based on the feedbacks obtained from three experts specialized in curricula and teaching. In the pilot testing, the questions in the forms were found comprehensible by the participants.

\subsection{Data analysis}

The data were analyzed through content analysis. The objective of content analysis is to reveal the facts which might be hidden in the data, to combine similar data under the frame of specific concepts and themes, and to organize and interpret them in a way to ensure their readability (Yıldırım \& Şimşek, 2013, p. 259). The analysis yielded 14 themes and 37 codes grouped under these 14 themes. The data were further analyzed by means of QDA (Qualitative Data Analysis) Miner Lite program.

\subsection{Validity and reliability}

Validity is an important aspect in qualitative studies, as in quantitative studies. It is significant in case studies to perform persistent observation, methodological triangulation, data (participant) triangulation and detailed descriptions for validity purposes (Creswell \& Miller, 2000). Focusing on 
data triangulation, this study includes the Turkish instructors serving in both primary education institutions and camps.

Cohen's (1960) Kappa test was conducted to ensure the reliability of the study. "Cohen's kappa coefficient" represents the agreement between two observers (Gordis, 2014; Cohen, 1960). As the variable tested for agreement is a categorical (nominal) variable, the statistics are non-parametric. Since "Cohen's $\kappa$ test" implies that the agreement may occur by chance, it is considered to yield a stronger result compared to the agreement between two raters specified in percentage (Fleiss, 1971; Cohen, 1960). There are two different probability measures in $\kappa$ coefficient: $\operatorname{Pr}(a)$ and $\operatorname{Pr}(\mathrm{e}) . \operatorname{Pr}(\mathrm{a})$ refers to the total observed agreement among the raters whilst $\operatorname{Pr}(\mathrm{e})$ is the hypothetical probability of a chance agreement. The formula for Cohen's $\kappa$ coefficient based on these two measures is as follows:

$$
\kappa=\frac{\operatorname{Pr}(\mathrm{a})-\operatorname{Pr}(\mathrm{e})}{1-\operatorname{Pr}(\mathrm{e})}
$$

Kappa value may range from (-)1 to (+)1 and the values are interpreted as follows (as cited in Kılıç, 2015):

- $\kappa=+1$ Excellent agreement between two raters.

- $\kappa=0$ Agreement as expected by chance alone.

- $\kappa=-1$ Great disagreement between two raters.

Below, possible $\kappa$ values are interpreted in Table 4 .

Table 4. Interpretations of $\kappa$ values (Landis \& Koch; 1977)

\begin{tabular}{cl}
\hline к value & Interpretation \\
\hline$<0$ & Less than chance agreement \\
$0.01-0.20$ & Slight agreement \\
$0.21-0.40$ & Fair agreement \\
$0.41-0.60$ & Moderate agreement \\
$0.61-0.80$ & Substantial agreement \\
$0.81-1.00$ & Almost perfect agreement \\
\hline
\end{tabular}

$2 \times 2$ tables are formed while calculating $\kappa$ as in Table 5. If the sums of rows and columns in the table are equal or close to each other, row and column sums are said to be close to each other. The more different these sums are from each other, the more unbalanced row and column sums become. This leads to asymmetrical row and column sums.

\subsection{The PABAK (Prevalence-Adjusted and Bias-Adjusted Kappa) coefficient}

The PABAK (Prevalence-Adjusted and Bias-Adjusted Kappa) is another compliance index suggested by Bryt et al. as an alternative to $\kappa$ coefficient. This approach, which eliminates two problems regarding $\kappa$ coefficient, is based on the calculation of problems according to prevalence and bias indeces (Sim \& Wright, 2005; Bryt et al., 1993).к is affected by the relative probabilities of "yes" and "no" values, and the difference between these probabilities is called the prevalence index. Thus, it is difficult 
to significantly interpret $\kappa$ alone without considering the prevalence index. When rater $\mathrm{A}$ and $\mathrm{B}$ give a different rating for a situation, this means there is a bias between raters. When there is a large bias, $\kappa$ is higher than when bias is low or absent. Sim and Wright in contrast to prevalence, the effect of bias is greater when $\kappa$ is small than when it is large (2005, cited in Bağ, Karabulut \& Alpar, 2010).

The PABAK compliance index between two raters adjusts kappa in terms of prevalence difference and bias between raters/ratings (Kundel \& Polansky, 2003). The PABAK coefficient is calculated through the following equation: $\operatorname{PABAK}=(2 * \operatorname{Pr}(\mathrm{a})-1)$. Asymmetrical row and column sums yield more acceptable values for kappa. The interpretation of the PABAK coefficient is the same as for kappa (Bağ, Karabulut \& Alpar, 2010).

Table 5. Numbers of yes and no by coders for the theme of reading

\begin{tabular}{llll}
\hline Coder 2 & & & \\
Coder 1 & Yes & No & Total \\
\hline Yes & 19 & 2 & 21 \\
No & 3 & 2 & 5 \\
Total & & & \\
& 22 & 4 & 26 \\
\hline
\end{tabular}

- The number of codes agreed by two coders is $21(19+2)$; the observed proportion of agreement is $\operatorname{Pr}(a)=21 / 26=0.81$.

$\operatorname{Pr}(\mathrm{e})$ value, the hypothetical probability of random agreement, is calculated as follows:

- The yes ratio of the Coder 1 is $21 / 26=0.81$ whilst the no ratio is $5 / 26=0.19$.

- The yes ratio of the Coder 2 is $22 / 26=0.85$ whilst the no ratio is $4 / 26=0.15$.

- The probability that the coders would randomly say yes is $0.85^{*} 0.81=0.69$; the probability that the coders would randomly say no is $0.15^{*} 0.19=0.03$. Thus, $\operatorname{Pr}$ (e) value, the hypothetical probability of random agreement, is $\operatorname{Pr}(\mathrm{e})=0.69+0.03=0.72$.

Inserting these calculations into Cohen's $\kappa$ Coefficient formula yields the following result: $\kappa=(0.81$ $0.72) /(1-0.72)=0,32$. However, as the row-column sums are asymmetrical, it is necessary to calculate the PABAK coefficient to interpret the result. The PABAK coefficient is calculated as PABAK $=(2 * \operatorname{Pr}$ (a)-1), thus the result is PABAK $=2 * 0.81-1=0.62$. This indicates substantial agreement.

Table 5 presents the calculation of inter-rater reliability coefficient for the theme of reading. This coefficient was not calculated for each theme in this study. As the row-column sums were asymmetrical for all themes, the PABAK coefficient for each time was calculated. The PABAK coefficients for other themes ranged between $0.54 \leq \kappa \leq 0.83$. The lowest value, 0.54 , was obtained in the theme of Problems regarding Teachers or Other Instructors in the Institution. This is a moderate agreement as can be seen in Table 4, which presents the interpretation of $\kappa$ values. The compliance values for other themes indicate substantial and almost perfect agreement. This implies that the study is reliable in determining its codes and themes. 


\section{Results}

3.1. Findings on the sub-problem of the problems faced in teaching Turkish to Syrian children regarding the four basic language skills (reading, writing, listening and speaking)

Table 6 presents the percentage and frequency distribution of the problems faced in teaching Turkish to Syrian children regarding reading skill, which is one of the four basic language skills.

Table 6. Problems regarding reading skill

\begin{tabular}{|c|c|c|c|c|}
\hline Themes & Codes & Participants & $\begin{array}{c}\text { Percentage } \\
\%\end{array}$ & $\begin{array}{c}\text { Frequency } \\
\text { f }\end{array}$ \\
\hline \multirow{4}{*}{ : } & $\begin{array}{l}\text { Pronunciation of vowels and } \\
\text { confusion of vowels }\end{array}$ & $\mathrm{I}_{1}, \mathrm{I}_{2}, \mathrm{I}_{4}, \mathrm{I}_{7}, \mathrm{I}_{9}, \mathrm{I}_{12}, \mathrm{I}_{14}, \mathrm{I}_{15}, \mathrm{I}_{16}, \mathrm{I}_{19}, \mathrm{I}_{25}$ & 42.31 & 11 \\
\hline & $\begin{array}{l}\text { Differences in alphabets } \\
\text { (reading backwards/reading } \\
\text { like English) }\end{array}$ & $\mathrm{I}_{3}, \mathrm{I}_{8}, \mathrm{I}_{10}, \mathrm{I}_{11}, \mathrm{I}_{13}$ & 19.23 & 5 \\
\hline & $\begin{array}{l}\text { Lack of reading } \\
\text { comprehension, reading } \\
\text { slowly and irrelevantly }\end{array}$ & $\mathrm{I}_{5}, \mathrm{I}_{6}, \mathrm{I}_{17}, \mathrm{I}_{21}, \mathrm{I}_{22}$ & 19.23 & 5 \\
\hline & $\begin{array}{l}\text { Inability to recognize letters } \\
\text { and to combine letters and } \\
\text { syllables }\end{array}$ & $\mathrm{I}_{18}, \mathrm{I}_{20}, \mathrm{I}_{21}, \mathrm{I}_{22}, \mathrm{I}_{23}$ & 19.23 & 5 \\
\hline
\end{tabular}

As seen in Table 6, there are some problems regarding reading skill in teaching Turkish to the Syrian children as a foreign language. Foremost among them is pronunciation of vowels and confusion of vowels, as reported by $\mathrm{n}=11$ of the instructors $(42.31 \%)$. The participant identified as $\mathrm{I}_{1}$ stated that "They usually cannot pronounce vowels correctly" and the participant identified as $\mathrm{I}_{2}$ reported "the confusion of vowels such as $\ddot{o}$-o and $u$ - $\ddot{u}$." One of the problems is differences in alphabets, as reported by $\mathrm{n}=5$ of the instructors (19.23\%). Indeed, the behaviours of reading backwards from the end due to the differences in the Latin and Arabic alphabets and reading Turkish words as if they were English were common among the Syrian students. Regarding this problem, the participant identified $\mathrm{I}_{3}$ pointed to "differences in the alphabets and misconceptions" and $\mathrm{I}_{8}$ stated that "regarding reading skill, they mostly read the words backwards" and $\mathrm{I}_{11}$ expressed that "They try to pronounce the words as in English. They cannot understand that the alphabet is different." Another problem concerning the reading skill of the Syrian students is their lack of reading comprehension, reading slowly and irrelevantly, as reported by $\mathrm{n}=5$ of the instructors (19.23\%). Mentioning "incorrect pronunciation of letters and slow reading" $\mathrm{I}_{5}$ also reported that "The problem of lack of reading comprehension is common" and $\mathrm{I}_{21}$ stated that "I can say that they make mistakes in reading letters and read slowly and also they do not read at the expected level." $\mathrm{n}=5$ of the instructors (19.23\%) expressed that the Syrian students are not able to recognize letters and to combine letters and syllables. In this regard, $\mathrm{I}_{18}$ articulated that "The students have difficulty in combining letters to form words" and $\mathrm{I}_{23}$ stated that "They cannot read words because they fail to grasp the concept of syllable."

Table 7 presents the percentage and frequency distribution of the problems faced in teaching Turkish to Syrian children regarding writing skill, which is one of the four basic language skills. Writing skills, planning of ideas, organization, presentation, vocabulary knowledge, syntax knowledge, etc. are skills that includes cases. However, in this study, it is used in the sense that students write the alphabet correctly. 
Table 7. Problems regarding writing skill

\begin{tabular}{|c|c|c|c|c|}
\hline Themes & Codes & Participants & $\begin{array}{c}\text { Percentage } \\
\%\end{array}$ & $\begin{array}{l}\text { Frequency } \\
\text { f }\end{array}$ \\
\hline \multirow{3}{*}{ 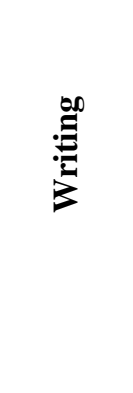 } & $\begin{array}{l}\text { Forgetting vowels in words and } \\
\text { mistaking some vowels for } \\
\text { others (e.g. o-ö and u-ü) }\end{array}$ & $\begin{array}{l}\mathrm{I}_{1}, \mathrm{I}_{2}, \mathrm{I}_{3}, \mathrm{I}_{5}, \mathrm{I}_{6}, \mathrm{I}_{10}, \mathrm{I}_{11}, \mathrm{I}_{12}, \mathrm{I}_{15} \mathrm{I}_{16,} \mathrm{I}_{17}, \mathrm{I}_{19}, \\
\mathrm{I}_{22}\end{array}$ & 48.15 & 13 \\
\hline & Writing backwards & $\mathrm{I}_{1}, \mathrm{I}_{7}, \mathrm{I}_{8}, \mathrm{I}_{9,}, \mathrm{I}_{11}, \mathrm{I}_{12}, \mathrm{I}_{14}, \mathrm{I}_{20}, \mathrm{I}_{23}$ & 33.33 & 9 \\
\hline & $\begin{array}{l}\text { Using imitation and disobeying } \\
\text { the rules to write }\end{array}$ & $\mathrm{I}_{4,} \mathrm{I}_{18}, \mathrm{I}_{20,} \mathrm{I}_{22,} \mathrm{I}_{25}$ & 18.52 & 5 \\
\hline
\end{tabular}

As seen in Table 7, there are some problems regarding writing skill in Turkish teaching to the Syrian children as a foreign language as well. $\mathrm{n}=13$ of the instructors $(48.15 \%)$ reported that the students forgot vowels in words and mistook some vowels for others (e.g. o-ö and u-ü), which is one of the most common problems in this skill. $\mathrm{I}_{5}$ stated that "One of the problems is that they forget vowels" and $\mathrm{I}_{22}$ mentioned about "forgetting about vowels in words and misspelling." Another problem for this skill is writing backwards, as reported by $\mathrm{n}=9$ of the instructors (33.33\%). $\mathrm{I}_{1}$ expressed that "they write from right to left as in Arabic" and $\mathrm{I}_{9}$ stated that "they have difficulty in writing as they are used to write from right to left." The last problem for writing skill is using imitation in writing letters and disobeying the rules to write, as reported by $\mathrm{n}=5$ of the instructors (18.52\%). In this regard, $\mathrm{I}_{4}$ stated that "They fail to distinguish between uppercase and lowercase letters while writing words" and $\mathrm{I}_{18}$ expressed that "They use imitation while writing. Some of them cannot even use imitation."

Table 8 presents the percentage and frequency distribution of the problems faced in teaching Turkish to Syrian children regarding listening skill, which is one of the four basic language skills.

Table 8. Problems regarding listening skill

\begin{tabular}{|c|c|c|c|c|}
\hline Themes & Codes & Participants & $\begin{array}{c}\text { Percentage } \\
\%\end{array}$ & $\begin{array}{c}\text { Frequency } \\
\mathbf{f}\end{array}$ \\
\hline \multirow{2}{*}{ 象 } & $\begin{array}{l}\text { Loss of motivation due to lack } \\
\text { of comprehension }\end{array}$ & $\mathrm{I}_{1}, \mathrm{I}_{6}, \mathrm{I}_{7}, \mathrm{I}_{8}, \mathrm{I}_{14}, \mathrm{I}_{15}, \mathrm{I}_{17}, \mathrm{I}_{21}, \mathrm{I}_{22}, \mathrm{I}_{23} \mathrm{I}_{25}$ & 64.71 & 11 \\
\hline & Poor listening skills & $\mathrm{I}_{5}, \mathrm{I}_{9}, \mathrm{I}_{12}, \mathrm{I}_{13}, \mathrm{I}_{18}, \mathrm{I}_{19}$ & 35.29 & 6 \\
\hline
\end{tabular}

As seen in Table 8, among the problems regarding listening skill in teaching Turkish to the Syrian children as a foreign language, the problem of loss of motivation due to lack of comprehension is the most common problem as reported by $n=11$ of the instructors $(64.71 \%)$. In this regard, $I_{7}$ stated that "They fail to understand what they listen" and $\mathrm{I}_{21}$ reported that "Most of the time, we cannot make them focus during listening as Turkish is a foreign language for them. They do not listen what they do not understand." Similarly, $\mathrm{n}=6$ of the instructors (35.29\%) mentioned about poor listening skills among the students. In fact, $\mathrm{I}_{9}$ expressed that "They are reluctant to listen. They should receive training on listening" and $\mathrm{I}_{19}$ emphasized that "In general, listening is a poor and an underdeveloped skill."

Table 9 presents the percentage and frequency distribution of the problems faced in teaching Turkish to Syrian children regarding speaking skill, which is one of the four basic language skills. 
Table 9. Problems regarding speaking skill

\begin{tabular}{|c|c|c|c|c|}
\hline Themes & Codes & Participants & $\begin{array}{c}\text { Percentage } \\
\%\end{array}$ & $\underset{f}{\text { Frequency }}$ \\
\hline \multirow{5}{*}{$\begin{array}{l}\text { 苛 } \\
\text { की } \\
\text { की }\end{array}$} & $\begin{array}{l}\text { Not needing to speak } \\
\text { Turkish }\end{array}$ & $\mathrm{I}_{1,} \mathrm{I}_{9,} \mathrm{I}_{11}, \mathrm{I}_{15}, \mathrm{I}_{17}, \mathrm{I}_{21}, \mathrm{I}_{22}$ & 28.00 & 7 \\
\hline & Pronunciation & $\mathrm{I}_{4}, \mathrm{I}_{5}, \mathrm{I}_{6}, \mathrm{I}_{7}, \mathrm{I}_{18}, \mathrm{I}_{22}$ & 24.00 & 6 \\
\hline & $\begin{array}{l}\text { Speaking without using } \\
\text { tenses and suffixes }\end{array}$ & $\mathrm{I}_{3}, \mathrm{I}_{8}, \mathrm{I}_{10}, \mathrm{I}_{12}, \mathrm{I}_{19}$ & 20.00 & 5 \\
\hline & $\begin{array}{l}\text { Difficulties due to Turkish } \\
\text { sentence structure }\end{array}$ & $\mathrm{I}_{2,} \mathrm{I}_{3,} \mathrm{I}_{13}, \mathrm{I}_{25}$ & 16.00 & 4 \\
\hline & Poor vocabulary & $\mathrm{I}_{20}, \mathrm{I}_{22}, \mathrm{I}_{23}$ & 12.00 & 3 \\
\hline
\end{tabular}

As seen in Table 9, there are some problems regarding speaking skill in teaching Turkish to the Syrian children as a foreign language. Foremost among them is that they do not need to speak Turkish, as reported by $\mathrm{n}=7$ of the instructors (28\%). In this regard, $\mathrm{I}_{21}$ reported that "They speak Turkish only as much as they need. They are affected by the Arabic conversations at home." $\mathrm{I}_{1}$ stated that "They opt to speak Arabic on every occasion. They should feel the necessity to speak Turkish." Another common problem is pronunciation, as reported by $\mathrm{n}=6$ of the instructors (24\%). In fact, $\mathrm{I}_{7}$ expressed that "They cannot pronounce some letters while speaking"; $\mathrm{I}_{5}$ mentioned about "the problem of pronouncing the letters like $\ddot{o}, \ddot{u}$ and $i$ " while $\mathrm{I}_{6}$ reported that "The students cannot speak Turkish and pronounce the words correctly." Besides, speaking without using tenses and suffixes poses another problem for speaking skill, as mentioned by $\mathrm{n}=5$ of the instructors (20\%). In this regard, $\mathrm{I}_{3}$ reported "the misuse of suffixes and tenses" and $\mathrm{I}_{19}$ mentioned about "using the infinitive form of words while speaking and failing to use any suffix." Also, $\mathrm{n}=4$ of the instructors (16\%) expressed that there are some problems due to Turkish sentence structure. Indeed, $\mathrm{I}_{2}$ stated that "Sentence structure leads to difficulties in speaking" and $\mathrm{I}_{25}$ reported that "As they do not know the sentence structure in Turkish exactly, they form incorrect and meaningless sentences." Lastly, it is notable that there are some problems due to poor vocabulary, as agreed by $\mathrm{n}=3$ of the instructors $(12.00 \%)$. In this regard, $\mathrm{I}_{20}$ stated that "As they gradually learn the meanings of words, they have difficulty in speaking to that extent" and $\mathrm{I}_{23}$ reported that "They have poor speaking skills and vocabulary."

3.2. Findings on the sub-problem of "In teaching Turkish as a foreign language to Syrian children, what are the problems faced by Turkish instructors regarding the administration in the institution they work at, the teachers or other Turkish instructors in the institution they work at, the students in the institution, the parents of the students and the learning environment?"

Table 10 presents the percentage and frequency distribution of the codes formed based on the problems faced by Turkish instructors in teaching Turkish as a foreign language to the Syrian children regarding the administration in the institution they work at. 
Table 10. Problems regarding the administration

\begin{tabular}{|c|c|c|c|c|}
\hline Themes & Codes & Participants & $\begin{array}{c}\text { Percentage } \\
\%\end{array}$ & $\begin{array}{l}\text { Frequency } \\
\text { f }\end{array}$ \\
\hline 里 & $\begin{array}{l}\text { Indifferent and adverse } \\
\text { behaviors exhibited by the } \\
\text { administration }\end{array}$ & $\mathrm{I}_{1}, \mathrm{I}_{3}, \mathrm{I}_{4}, \mathrm{I}_{5}, \mathrm{I}_{11}, \mathrm{I}_{20}, \mathrm{I}_{21}, \mathrm{I}_{22}$ & 57.14 & 8 \\
\hline ค & $\begin{array}{l}\text { Uncertain work hours and } \\
\text { lack of a schedule }\end{array}$ & $\mathrm{I}_{3}, \mathrm{I}_{10}, \mathrm{I}_{11}, \mathrm{I}_{15}, \mathrm{I}_{16}, \mathrm{I}_{22}$ & 42.86 & 6 \\
\hline
\end{tabular}

As observed in Table 10, there are several problems faced by Turkish instructors in teaching Turkish as a foreign language to the Syrian children regarding the administration in the institution they work at. Of the participants, $\mathrm{n}=8$ (57.14\%) reported indifferent and adverse behaviors exhibited by the administration. Indeed, $\mathrm{I}_{11}$ stated that "The administration is indifferent and imposes mobbing to us" and $\mathrm{I}_{3}$ reported that "We are not recognized as teachers. They do not know what we do or expect us to work a miracle." Further, $\mathrm{n}=6(42.86 \%)$ of the participants considered uncertain work hours and lack of a schedule as a problem. $\mathrm{I}_{15}$ mentioned about "Uncertain work hours. This should be specified in the contract" while $\mathrm{I}_{10}$ reported "Assigning overtime work."

Table 11 presents the percentage and frequency distribution of the codes formed based on the problems faced by Turkish instructors in teaching Turkish as a foreign language to the Syrian children regarding the teachers or other Turkish instructors in the institution they work at.

Table 11. Problems regarding teachers or other instructors in the institution

\begin{tabular}{|c|c|c|c|c|}
\hline Themes & Codes & Participants & $\begin{array}{c}\text { Percentage } \\
\%\end{array}$ & $\begin{array}{c}\text { Frequency } \\
\text { f }\end{array}$ \\
\hline \multirow{4}{*}{ 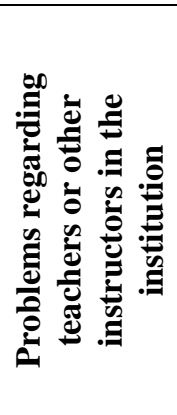 } & $\begin{array}{l}\text { Negative behaviors of the } \\
\text { teachers in the institution }\end{array}$ & $\mathrm{I}_{1}, \mathrm{I}_{2,} \mathrm{I}_{3,} \mathrm{I}_{11}, \mathrm{I}_{13}, \mathrm{I}_{14}, \mathrm{I}_{16}, \mathrm{I}_{18}$ & 57.14 & 8 \\
\hline & Lack of cooperation & $\mathrm{I}_{2,} \mathrm{I}_{9}, \mathrm{I}_{6}, \mathrm{I}_{23}$ & 28.57 & 4 \\
\hline & $\begin{array}{l}\text { Negative behaviors of } \\
\text { instructors }\end{array}$ & $\mathrm{I}_{13}$ & 7.14 & 1 \\
\hline & Merit & $\mathrm{I}_{13}$ & 7.14 & 1 \\
\hline
\end{tabular}

As observed in Table 11, there are several problems faced by Turkish instructors in teaching Turkish as a foreign language to the Syrian students regarding the teachers or other Turkish instructors in the institution they work at. The most common problem is the negative behaviors exhibited by the teachers in the institution, as reported by $\mathrm{n}=8$ (57.14\%). In this regard, $\mathrm{I}_{1}$ reported that "Teachers consider this project as an easy task and unnecessary and regard us someone to get shed of students" and $\mathrm{I}_{11}$ stated that "The permanent staff do not want to lecture Syrian students and pay attention to them." Another problem is the lack of cooperation as agreed by $\mathrm{n}=4(28.57 \%)$. $\mathrm{I}_{9}$ mentioned about "the lack of cooperation among the permanent staff" and $\mathrm{I}_{23}$ expressed that "Arabic and Turkish teachers do not get along with each other." $\mathrm{I}_{13}$ emphasized the negative behaviors exhibited by the instructors and the problems regarding merit. The participant stated that "Other Turkish instructors are irresponsible, selfordained and incapable." 
Table 12 presents the percentage and frequency distribution of the codes formed based on the problems faced by Turkish instructors in teaching Turkish as a foreign language to the Syrian children regarding the Syrian students in the institution.

Table 12. Problems regarding Syrian students

\begin{tabular}{|c|c|c|c|c|}
\hline Themes & Codes & Participants & $\begin{array}{c}\text { Percentage } \\
\%\end{array}$ & $\begin{array}{l}\text { Frequency } \\
\text { f }\end{array}$ \\
\hline \multirow{3}{*}{ 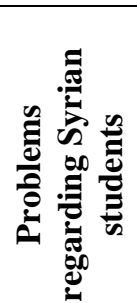 } & Lack of interest & $\begin{array}{l}\mathrm{I}_{1}, \mathrm{I}_{4}, \mathrm{I}_{5}, \mathrm{I}_{6}, \mathrm{I}_{7}, \mathrm{I}_{8}, \mathrm{I}_{10}, \mathrm{I}_{11}, \mathrm{I}_{12}, \mathrm{I}_{13}, \mathrm{I}_{14}, \mathrm{I}_{16}, \mathrm{I}_{19}, \\
\mathrm{I}_{20}, \mathrm{I}_{23}, \mathrm{I}_{25}\end{array}$ & 64.00 & 16 \\
\hline & $\begin{array}{l}\text { Discipline problems and } \\
\text { violence }\end{array}$ & $\mathrm{I}_{3,} \mathrm{I}_{9}, \mathrm{I}_{10}, \mathrm{I}_{11}, \mathrm{I}_{16}, \mathrm{I}_{22}, \mathrm{I}_{25}$ & 28.00 & 7 \\
\hline & Lack of a holiday break & $\mathrm{I}_{14}, \mathrm{I}_{16}$ & 8.00 & 2 \\
\hline
\end{tabular}

As observed in Table 12, there are several problems faced by Turkish instructors in teaching Turkish as a foreign language to the Syrian students regarding the Syrian students. The most common problem is the lack of interest among the students in learning Turkish, as reported by $n=16(64.00 \%)$ of the participants. Indeed, $\mathrm{I}_{6}$ stated that "The students are unwilling to learn"; $\mathrm{I}_{14}$ reported that "The students settle for what they learn in the course and do not make any effort" and $\mathrm{I}_{20}$ expressed that "The students are very self-ordained and cannot focus on the course." Also, discipline problems and violence poses a significant problem regarding the students, as reported by $\mathrm{n}=7(28.00 \%)$ of the participants. Indeed, $\mathrm{I}_{9}$ argued that "The students are very undisciplined. Sanctions should be applied" and $\mathrm{I}_{11}$ stated that "Disrespect, contempt and lack of exam anxiety are common among the students." Further, $\mathrm{n}=2(8.00 \%)$ of the participants mentioned the lack of a holiday break for the Syrian students. Indeed, $\mathrm{I}_{14}$ reported that "Also, due to the lack of any holiday break, the students are prejudiced to learn Turkish" and $\mathrm{I}_{16}$ mentioned about "... and the students are going to the school in every non-business day."

Table 13 presents the percentage and frequency distribution of the codes formed based on the problems faced by Turkish instructors in teaching Turkish as a foreign language to the Syrian children regarding the parents.

Table 13. Problems regarding parents

\begin{tabular}{llll}
\hline \multicolumn{1}{c}{ Codes } & \multicolumn{1}{c}{ Participants } & $\begin{array}{c}\text { Percentage } \\
\text { \% }\end{array}$ & $\begin{array}{c}\text { Frequency } \\
\text { f }\end{array}$ \\
\hline & Parental indifference & $\mathrm{I}_{1}, \mathrm{I}_{3}, \mathrm{I}_{5}, \mathrm{I}_{6}, \mathrm{I}_{7}, \mathrm{I}_{8}, \mathrm{I}_{9}, \mathrm{I}_{11}, \mathrm{I}_{12}, \mathrm{I}_{13}, \mathrm{I}_{14}, \mathrm{I}_{15}, \mathrm{I}_{17}, \mathrm{I}_{19}$, & 62.96 \\
$\mathrm{I}_{22}, \mathrm{I}_{23}, \mathrm{I}_{25}$ & & 17 \\
& & $\mathrm{I}_{3}, \mathrm{I}_{4}, \mathrm{I}_{16}, \mathrm{I}_{18}, \mathrm{I}_{19}, \mathrm{I}_{20}$ & 22.22 \\
\\
\hline
\end{tabular}

As observed in Table 13, there are several problems faced by Turkish instructors in teaching Turkish as a foreign language to the Syrian students regarding the parents of the Syrian students. Foremost among them is parental indifference, as mentioned by $\mathrm{n}=17$ (62.96\%). In this regard, $\mathrm{I}_{7}$ stated that "The parents are indifferent" and $\mathrm{I}_{25}$ reported that "The parents are indifferent as they have many children." 
Another problem is the lack of communication, as reported by $\mathrm{n}=6(22.22 \%)$. Indeed, $\mathrm{I}_{4}$ stated that " $A s$ teachers, we are not able to communicate with the parents" and $\mathrm{I}_{20}$ expressed that "They do not speak Turkish and understand what the problem is." Moreover, the parents put pressure on their children not to learn Turkish and exhibit behaviors that prevent them from learning Turkish. The parental behaviors that prevent the students from learning are reported by $\mathrm{n}=4(14.82 \%)$. $\mathrm{I}_{10}$ stated that "The parents do not encourage their children to speak Turkish" and $\mathrm{I}_{22}$ mentioned about "...parental pressure and failing to recognize the importance of learning Turkish."

Table 14 presents the percentage and frequency distribution of the codes formed based on the problems faced by Turkish instructors in teaching Turkish as a foreign language to the Syrian children regarding the learning environment in the institution.

Table 14. Problems regarding the learning environment

\begin{tabular}{|c|c|c|c|c|}
\hline Themes & Codes & Participants & $\begin{array}{c}\text { Percentage } \\
\%\end{array}$ & $\begin{array}{l}\text { Frequency } \\
\mathbf{f}\end{array}$ \\
\hline \multirow{5}{*}{ 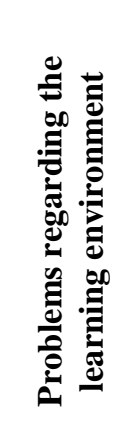 } & $\begin{array}{l}\text { Insufficient number of } \\
\text { classrooms }\end{array}$ & $\mathrm{I}_{1,} \mathrm{I}_{2,} \mathrm{I}_{3}, \mathrm{I}_{6}, \mathrm{I}_{7}, \mathrm{I}_{8}, \mathrm{I}_{11}, \mathrm{I}_{13}, \mathrm{I}_{15}, \mathrm{I}_{16}, \mathrm{I}_{17}, \mathrm{I}_{20}, \mathrm{I}_{23}$ & 29.55 & 13 \\
\hline & Lack of materials & $\mathrm{I}_{2,} \mathrm{I}_{4}, \mathrm{I}_{5}, \mathrm{I}_{9}, \mathrm{I}_{10}, \mathrm{I}_{11}, \mathrm{I}_{13}, \mathrm{I}_{14}, \mathrm{I}_{17}, \mathrm{I}_{19}, \mathrm{I}_{23}, \mathrm{I}_{24}$ & 27.27 & 12 \\
\hline & $\begin{array}{l}\text { Lack of classroom } \\
\text { equipment }\end{array}$ & $\mathrm{I}_{2}, \mathrm{I}_{3}, \mathrm{I}_{4}, \mathrm{I}_{5}, \mathrm{I}_{9}, \mathrm{I}_{10}, \mathrm{I}_{13}, \mathrm{I}_{17}, \mathrm{I}_{18}, \mathrm{I}_{22}$ & 22.73 & 10 \\
\hline & Overcrowded classroom & $\mathrm{I}_{2,}, \mathrm{I}_{19}, \mathrm{I}_{20}, \mathrm{I}_{23}, \mathrm{I}_{24}$ & 11.36 & 5 \\
\hline & $\begin{array}{l}\text { Cleaning, heating and } \\
\text { cooling }\end{array}$ & $\mathrm{I}_{3}, \mathrm{I}_{4}, \mathrm{I}_{21}, \mathrm{I}_{22}$ & 9.09 & 4 \\
\hline
\end{tabular}

As seen in Table 14, there are several problems faced by Turkish instructors in teaching Turkish as a foreign language to the Syrian students regarding the learning environment. The most common problem is the insufficient number of classrooms, as mentioned by $n=13(29.55 \%)$ of the participants. Indeed, $\mathrm{I}_{7}$ expressed that "There is not enough classroom. We should be provided with an environment" and $\mathrm{I}_{15}$ also stated that "No classroom is available due to the learning environment" and $\mathrm{I}_{23}$ emphasized "the problem of materials and classrooms." Further, the lack of materials is one of the most common problem, as mentioned by $\mathrm{n}=12(25.58 \%)$. In this regard, $\mathrm{I}_{2}$ reported that "There is no book, no classroom, no interactive whiteboard" and $\mathrm{I}_{19}$ mentioned about "the lack of enough sources and materials in the learning environment." The lack of classroom equipment poses another problem, as reported by $\mathrm{n}=10(22.73 \%)$. In fact, $\mathrm{I}_{5}$ mentioned about "the lack of materials and classroom equipment" while $\mathrm{I}_{13}$ articulated that "There are no materials in the learning environment and the classroom is nothing other than a room." Overcrowded classrooms are also a problem in relation to the learning environment. $\mathrm{n}=5(11.36 \%)$ of the participants mentioned about overcrowded classrooms. $\mathrm{I}_{2}$ argued that "The Syrian students are not homogeneously present in the schools, and 500 Syrian in one classroom cannot learn Turkish" and $\mathrm{I}_{24}$ reported that "The classrooms are crowded." Although it is not that common, cleaning, heating and cooling also pose a problem, as reported by $\mathrm{n}=5(9.09 \%)$. $\mathrm{I}_{3}$ mentioned about "the problem of cooling and heating" and $\mathrm{I}_{22}$ stated that "Also, there are some problems about disciplinary and cleaning." 
3.3. Findings on the sub-problem of "To what extent do the Turkish instructors utilize instructional technologies in teaching Turkish to Syrian children?"

Table 15 presents the percentage and frequency distribution of the codes formed based on the use of instructional technologies among Turkish instructors teaching Turkish to the Syrian children as a foreign language.

Table 15. Use of instructional technologies among instructors

\begin{tabular}{|c|c|c|c|c|}
\hline Themes & Codes & Participants & $\begin{array}{c}\text { Percentage } \\
\%\end{array}$ & $\begin{array}{c}\text { Frequency } \\
\mathbf{f}\end{array}$ \\
\hline ซ్ & I use these technologies & $\mathrm{I}_{1}, \mathrm{I}_{2,} \mathrm{I}_{3}, \mathrm{I}_{5}, \mathrm{I}_{6}, \mathrm{I}_{7}, \mathrm{I}_{8}, \mathrm{I}_{9}, \mathrm{I}_{10}, \mathrm{I}_{12}, \mathrm{I}_{19}, \mathrm{I}_{21}$ & 50.00 & 12 \\
\hline 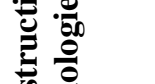 & I do not use these technologies & $\mathrm{I}_{11}, \mathrm{I}_{13}, \mathrm{I}_{15}, \mathrm{I}_{16}, \mathrm{I}_{18}, \mathrm{I}_{20}, \mathrm{I}_{23}, \mathrm{I}_{24}, \mathrm{I}_{25}$ & 37.50 & 9 \\
\hline 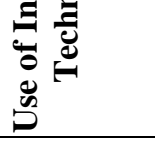 & $\begin{array}{l}\text { I sometimes use these } \\
\text { technologies }\end{array}$ & $\mathrm{I}_{4}, \mathrm{I}_{17}, \mathrm{I}_{22}$ & 12.50 & 3 \\
\hline
\end{tabular}

As observed in Table 15, $\mathrm{n}=12(50.00 \%)$ of the participants reported that they use instructional technologies in teaching Turkish to the Syrian children as a foreign language. $\mathrm{I}_{5}$ mentioned about "reproducing materials through interactive whiteboards and copiers" while $\mathrm{I}_{21}$ stated that "I use computer and audio system." $\mathrm{n}=3(12.50 \%)$ of the participants stated that they sometimes use these technologies. $\mathrm{I}_{4}$ expressed that "I use the interactive whiteboard whenever I get a chance" and $\mathrm{I}_{22}$ articulated that "The environment lacks technological tools. I sometimes bring my own laptop." $\mathrm{n}=9$ (37.50\%) stated that they do not use these technologies. In this regard, $\mathrm{I}_{15}$ mentioned that "There is no material for instructional technologies, so we do not use them" and $\mathrm{I}_{23}$ stated that "I do not use instructional technologies."

3.4. Findings on the sub-problem of "What opinions do Turkish instructors have about the extent to which the certification program for teaching Turkish as a foreign language they participated is useful in teaching Turkish to determine the outcomes, to present and organize the content, to use teaching methods and techniques and to measure and evaluate students?"

The instructors assigned to teach Turkish to Syrian students as a foreign language participated in a certification program titled "Certification Program for Teaching Turkish as a Foreign Language" which includes 64 hours of theoretical training and 10 hours of practical training in coordination with the universities in the provinces they work and the national education directorate. Table 16 presents their opinions on the dimensions of the program.

Table 16. Opinions of instructors on their participation in the certification program

\begin{tabular}{|c|c|c|c|c|}
\hline Themes & Codes & Participants & $\begin{array}{c}\text { Percentage } \\
\%\end{array}$ & $\begin{array}{c}\text { Frequency } \\
\text { f }\end{array}$ \\
\hline \multirow{3}{*}{ } & It was helpful & $\mathrm{I}_{1}, \mathrm{I}_{5}, \mathrm{I}_{10}, \mathrm{I}_{12}, \mathrm{I}_{15}, \mathrm{I}_{16}, \mathrm{I}_{20}, \mathrm{I}_{21}, \mathrm{I}_{22}, \mathrm{I}_{23}$ & 52.63 & 10 \\
\hline & $\begin{array}{l}\text { It was somewhat } \\
\text { helpful }\end{array}$ & $\mathrm{I}_{2}, \mathrm{I}_{13}$ & 10.53 & 2 \\
\hline & It was not helpful & $\mathrm{I}_{3}, \mathrm{I}_{4}, \mathrm{I}_{7}, \mathrm{I}_{8}, \mathrm{I}_{9}, \mathrm{I}_{19}, \mathrm{I}_{24}$ & 36.84 & 7 \\
\hline
\end{tabular}


Continued Table 16

\begin{tabular}{|c|c|c|c|c|}
\hline Themes & Codes & Participants & $\begin{array}{c}\text { Percentage } \\
\%\end{array}$ & $\begin{array}{c}\text { Frequency } \\
\text { f }\end{array}$ \\
\hline \multirow{3}{*}{ 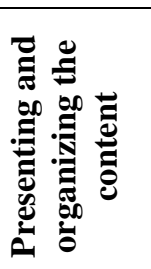 } & It was helpful & $\mathrm{I}_{5}, \mathrm{I}_{10}, \mathrm{I}_{12}, \mathrm{I}_{14}, \mathrm{I}_{15}, \mathrm{I}_{16}, \mathrm{I}_{24}$ & 41.18 & 7 \\
\hline & $\begin{array}{l}\text { It was somewhat } \\
\text { helpful }\end{array}$ & $\mathrm{I}_{11,}, \mathrm{I}_{13}, \mathrm{I}_{20}, \mathrm{I}_{21}, \mathrm{I}_{22}$ & 29.41 & 5 \\
\hline & It was not helpful & $\mathrm{I}_{2}, \mathrm{I}_{3}, \mathrm{I}_{4}, \mathrm{I}_{7}, \mathrm{I}_{9}$ & 29.41 & 5 \\
\hline \multirow{3}{*}{ 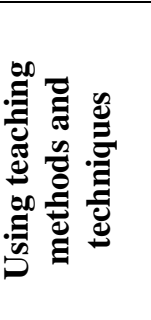 } & It was helpful & $\mathrm{I}_{1}, \mathrm{I}_{5}, \mathrm{I}_{10}, \mathrm{I}_{11}, \mathrm{I}_{12,}, \mathrm{I}_{15}, \mathrm{I}_{16}, \mathrm{I}_{22}$ & 42.11 & 8 \\
\hline & $\begin{array}{l}\text { It was somewhat } \\
\text { helpful }\end{array}$ & $\mathrm{I}_{13}, \mathrm{I}_{8}$ & 10.53 & 2 \\
\hline & It was not helpful & $\mathrm{I}_{2,} \mathrm{I}_{3,} \mathrm{I}_{4}, \mathrm{I}_{7}, \mathrm{I}_{8}, \mathrm{I}_{9,} \mathrm{I}_{19}, \mathrm{I}_{20,} \mathrm{I}_{24}$ & 47.36 & 9 \\
\hline \multirow{3}{*}{ 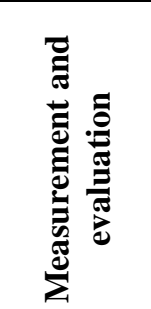 } & It was helpful & $\mathrm{I}_{5}, \mathrm{I}_{12}, \mathrm{I}_{14}, \mathrm{I}_{15}, \mathrm{I}_{16}, \mathrm{I}_{23}, \mathrm{I}_{24}$ & 41.18 & 7 \\
\hline & $\begin{array}{l}\text { It was somewhat } \\
\text { helpful }\end{array}$ & $\mathrm{I}_{8}, \mathrm{I}_{10}, \mathrm{I}_{11}, \mathrm{I}_{13}$ & 23.53 & 4 \\
\hline & It was not helpful & $\mathrm{I}_{1}, \mathrm{I}_{2}, \mathrm{I}_{3}, \mathrm{I}_{4}, \mathrm{I}_{7}, \mathrm{I}_{9}$ & 35.29 & 6 \\
\hline
\end{tabular}

As seen in Table 16, $\mathrm{n}=10(52.63 \%)$ stated that the certification program was helpful in the dimension of determining outcomes for the instructors teaching Turkish to the Syrian students as a foreign language whilst $\mathrm{n}=2(10.53 \%)$ stated that it was somewhat helpful. In this regard, $\mathrm{I}_{5}$ expressed that "The certification program was helpful in organizing outcomes and the content" and $\mathrm{I}_{10}$ stated that "It was efficient in determining outcomes, teaching methods and techniques." And, $\mathrm{I}_{2}$ expressed that "It would be better if there were more detailed examples for outcomes." $n=7(36.84 \%)$ of the participants reflected that the certification program was not helpful. $\mathrm{I}_{3}$ articulated that "The certification program is shortterm and it is not presented in the way that it is relevant to what we do. I do not think that a training for the individuals and adults learning a foreign language provided any help for the PICTES staff. Preparations should have been made and attention should have been paid to the training" and $\mathrm{I}_{19}$ stated that "The certification program was more about teaching Turkish to adults. The age-group level in the training should be younger."

Table 16 shows that $n=7$ (41.18\%) stated that the certification program was helpful in the dimension of presenting and organizing the content for the instructors teaching Turkish to the Syrian students as a foreign language whilst $\mathrm{n}=5$ (29.41\%) stated that it was somewhat helpful. In this regard, $\mathrm{I}_{5}$ reflected that "The certification program was helpful in organizing outcomes and the content" and $\mathrm{I}_{12}$ stated that "It was helpful." On the other hand, $\mathrm{I}_{20}$ reported that "I can say that it was somewhat helpful in presenting and organizing the content." The number of the participants who expressed that the program was not helpful in presenting and organizing the content is $\mathrm{n}=5(29.41 \%)$. $\mathrm{I}_{9}$ reflected that "The certification program was not efficient. The teachers experienced in this field should lecture" and $\mathrm{I}_{4}$ stated that "The certification program was lacking." 
Table 16 demonstrates that $n=8(42.11 \%)$ stated that the certification program was helpful in the dimension of using teaching techniques and methods for the instructors teaching Turkish to the Syrian students as a foreign language whilst $\mathrm{n}=2(10.53 \%)$ stated that it was somewhat helpful. Indeed, $\mathrm{I}_{1}$ reported that "It was useful to know the methods and techniques suitable for foreigners" and $\mathrm{I}_{1}$ reflected that "It was helpful in using teaching methods and techniques" whilst $\mathrm{I}_{13}$, pointing to all dimensions in the program, stated that "The certification program was not efficient. The teachers experienced in this field should lecture." The number of the participants who expressed that the program was not helpful in using teaching methods and techniques is $\mathrm{n}=9(47.36 \%)$. In fact, $\mathrm{I}_{2}$ stated that "We already had a lecture on teaching methods and techniques in the university" and $\mathrm{I}_{8}$ "The program was considerably inefficient in methods and techniques as well as measurement and evaluation. I think that the program should be long-term."

Table 16 shows that $n=7$ (41.18\%) stated that the certification program was helpful in the dimension of measurement and evaluation for the instructors teaching Turkish to the Syrian students as a foreign language whilst $\mathrm{n}=4$ (23.53\%) stated that it was somewhat helpful. In this regard, $\mathrm{I}_{12}$ reflected that "The certification program was helpful in measurement and evaluation" and $\mathrm{I}_{23}$ stated that "The certification program was helpful in determining outcomes and measurement and evaluation" whilst $\mathrm{I}_{11}$ reported that "The program was lacking in presenting and organizing the content as well as measurement and evaluation. It was helpful in using teaching methods and techniques." $\mathrm{n}=6(35.29 \%)$ of the participants reflected that the program was not helpful in the dimension of measurement and evaluation. $\mathrm{I}_{1}$ stated that "We were not provided much information on measurement and evaluation" and Ig expressed that "The certification program was lacking in measurement and evaluation. The teachers experienced in this field should lecture this course."

\section{Discussion}

The importance of teaching Turkish as a foreign language has recently increased. Over the past years, many people of Syrian origin have entered to Turkey due to the problems occurring in its neighboring country, Syria, in its southeastern border. With the entry of many people of school age to Turkey and the resulting need to receive education, learning Turkish has become a must for these people to adapt to Turkey.

It is notable that studies on teaching Turkish as a foreign language in the literature have focused on teaching Turkish to Syrians as a foreign language (Moral1, 2018; Öztürk, 2018; Aykır1, 2017; Erdem, 2017; Büyükikiz \& Çangal, 2016; Demirci, 2015; Dönmez \& Paksoy, 2015; Levent \& Çayak, 2017; Sarıtaş, Şahin \& Çatalbaş, 2016; Gürler, 2019).

This study first reviewed the studies on the problems faced in teaching Turkish as a foreign language to Syrians and formed the themes based on the problems. The study addressed Turkish teaching in detail in terms of four basic language skills (reading, writing, listening and speaking). Further, it looked into the use of instructional technologies in teaching Turkish to Syrians as a foreign language and evaluated a certification program based on qualitative data on the effectiveness of the Certification Program for Teaching Turkish as a Foreign Language created by TÖMER that the Turkish instructors assigned to teach Turkish participated in.

Among the problems faced in teaching Turkish as a foreign language to the Syrian children in terms of the four basic language skills, there are some problems regarding the reading skill. Reading is the process of seeing, perceiving and comprehending a text, words, sentences, punctuation marks and other elements in the text (Kavcar et al., 1999). Foremost among the problems regarding the reading skill are the pronunciation of vowels and confusion of vowels, followed by differences in alphabets, lack of 
reading comprehension, reading slowly and irrelevantly, inability to recognize letters and to combine letters and syllables. Demirci's (2015) study titled "Determinations Related to Reading Aloud Skills of Syrian Turkish-Learning Students in Level B1" focuses on the reading aloud skills of the Syrian students learning Turkish at TÖMER of Kahramanmaraş Sütçü İmam University and concludes that the students, despite being at level B1, make several mistakes while practicing reading aloud skills. Demirci (2015) argues that the differences between the alphabets, sounds and structures of the acquired language and target language are effective in the mistakes that the students make while reading aloud, and claims that the mood and motivation of the students, their attitudes and behaviors related to speaking, the physical conditions and content of the materials used in the course are other elements that adversely affect the reading skill. According to Demirci (2015), this problem in speaking permeates reading aloud practices and manifests itself as the problem of mistaking the sounds such as "o-u, ö-ü, p-b" for each other.

One of the elements that impact one's reading speed is the words not known or seen before. It is remarkable that relevant studies performed in the recent years have yielded new concepts. Introducing the concepts of "active and passive vocabulary wealth", Karakuş (2000) defines "active vocabulary wealth" as all of the vocabulary items known and used by a person while speaking or writing and "passive vocabulary wealth" as the vocabulary items understood by a person only when she reads or hears it, but not used by him/her while forming a text (Karakuş, 2000, pp. 128-129). The unknown words in a text slow down the reading speed. When one cannot understand the meaning of these words through the context they are used in, it becomes more difficult for him/her to understand the text. For that reason, feedbacks should be regularly given. This leads to reading errors such as spelling and stuttering. Therefore, students should be provided with texts including the words in their passive vocabulary wealth (Özbay, 2007, p. 12).

Among the problems faced in teaching Turkish as a foreign language to the Syrian children in terms of the four basic language skills, there are some problems regarding the writing skill. Writing is a way of communicating, expressing our feelings, thoughts and ideas, what we see and experience (Ünalan, 2006). The most common problem is forgetting vowels in words and mistaking some vowels for others (e.g. o-ö and u-ü). In Bölükbaş’s (2011) study titled “An Evaluation of Arab Students' Turkish Writing Skills", the students mentioned that vowels are written as signs, not as letters in the interviews and considered this as the major reason why they had difficulty in this skill. They further stated that the pronunciation of the vowels "o" and "ö", "u" and "ü", "a" and "e" is almost the same and thus they were uncertain about which one to use while forming a text. Moreover, one of the most common problems is writing backwards due to the differences between the two alphabets.

One of the overall objectives of teaching a foreign language is to enable students to speak the language they are learning in a clear way (Demirel, 2004, p. 94). Among the problems faced in teaching Turkish as a foreign language to the Syrian children in terms of the four basic language skills, there are some problems regarding the speaking skill as well. The most common one is not needing to speak Turkish. Pronunciation is an important problem, too. In their study titled "Evaluation of Written Expressions of Turkish Learners as a Foreign Language According to Error Analysis Approach", Büyükikiz \& Hasırc1 (2013) report that speaking Turkish, particularly in certain subjects, is difficult, that teachers and students have different responsibilities inside and outside the classroom to improve the speaking skill, that environment affects the speaking skill, that some sounds are difficult to pronounce, and that one's native language affects his/her Turkish speaking. Most of the participants reflected that speaking Turkish is difficult. The reasons can be considered under four main headings:

1. Turkish has many suffixes,

2. It is difficult to pronounce the words,

3. It is difficult to form a sentence in accordance with the grammatical rules of Turkish, 
4. It is difficult to use the acquired words in the correct context and time.

In the same study, the participants stated that they did not have much difficulty in Turkish constants in terms of pronunciation, but the vowels 1-i-o-ö-u-ü were problematic. Another problem is speaking without using tenses and suffixes. It is notable that the students generally confuse the accusative case suffix and the dative suffix and mostly forget to use the accusative case suffix (Özkan, Demir \& Özdemir, 2017; Bölükbaş, 2011).

Arabic and Turkish belong to different language families. Arabic belongs to the Semitic branch of the Hamitic-Semitic language family (Bilgegil, 2009, p. 12), is a member of the Semitic sub-group of the Afro-Asiatic group of languages (Buran-Yüksel Çak, 2012, p. 176) and an inflected language (Karaağaç, 2013, p. 71). On the other hand, Turkish belongs to the Altaic branch of the Ural-Altaic language family (Ergin, 1998, p. 9) and is an agglutinative language (Demir, 2004, p. 23). The difference between these two languages in regard to structure and origin leads to certain disadvantages in teaching Turkish to Arabic people as a foreign language. Indeed, the grammatical structure of these two languages are considerably different from each other. Perceiving Turkish as a language totally different from Arabic while learning Turkish mostly prevents negative transfer. A Turkish sentence follows the subjectobject-verb order. The sentence structure in Arabic is substantially different from that in Turkish. In Arabic, a sentence starting with a noun is called "a nominal sentence" while a sentence starting with a verb is called "a verbal sentence" (as cited in Aydın, 2007; İşler \& Yıldız, 2002). In Büyükikiz's (2014) study, one of the Syrian participants mentioned the problems arising due to the sentence structure of Turkish and reflected that "My native language is Arabic. Verbs are at the end of the sentence in Turkish while they are at the beginning in Arabic..." and "I do not have any difficulty. Since Arabic and Turkish are similar in terms of words. I have some difficulty only in verbs because the sentence structure in Arabic and Turkish is very different."

Listening, which is one of the comprehension skills, is significant in that it underlies other trainings for other skills in teaching a foreign language. Listening skill is the first and most used skill among the four basic language skills. This skill is improved in line with one's mental development (Özbay, 2012, p. 69). Listening skill is the skill first acquired by a person and most used for the rest of his/her life (Özbay, 2012; Coşkun, 2007; Lundsteen, 1979; Yalçın, 2002; Makodia, 2009; Cemiloğlu, 2004; Robertson, 2008; Gögüss, 1978; Buzan, 2006). According to Robertson (2008), the correlation between the listening skill and the level of success of students with average intelligence is higher than the correlation between their level of intelligence and level of success. Proper listening is critical for effective learning (Aydın, 2009). Hagevik (1999) states that a person spends $40 \%$ of his/her time to listening, 35\% to speaking, $16 \%$ to reading and $9 \%$ to writing (as cited in Cihangir, 2004). Among the problems faced in teaching Turkish as a foreign language to the Syrian children in terms of the four basic language skills, there are some problems regarding the listening skill. The most common problem is loss of motivation due to lack of comprehension. Poor listening skills pose a problem as well. In Büyükikiz's (2014) study, almost all the participants agree that it is difficult to perform listening in the subjects of politics, economics, and science and that it is easy to perform listening in the subjects of sports, news and art. This can be explained with the fact that the subjects found by the students found as difficult to listen to are not widely discussed in daily life while the subjects easy to listen are commonly discussed in everyday life.

There are some problems regarding the administration in the institution in teaching Turkish as a foreign language to the Syrian children. These are indifferent and adverse behaviors exhibited by the administration and uncertain work hours and lack of a schedule. There are also some problems regarding teachers and other instructors at the institution. Lack of cooperation as well as negative behaviors of the teachers at the institution are among these problems. Only one of the participants mentioned about the negative behaviors of the instructors and one participant also brought forward the issue of merit. 
Besides, some problems regarding the Syrian students in teaching Turkish as a foreign language to the Syrian children are present. One of the most common problems is the lack of interest to learn Turkish. The underlying reason may be the loss of motivation among the students to learn Turkish (Moral1, 2018). In their study on the students learning Turkish as a foreign language, Fatih Y1lmaz and Sevtap Buzlukluoğlu Arslan (2014) conclude on the aspect of motivation: "The most important external factor that affects students is teachers. For that reason, it is a must that teachers make the lesson fun to provide motivation in teaching Turkish to foreigners. Otherwise, the lesson becomes a chore and students lose their motivation. It is pivotal to provide motivation while teaching Turkish to foreigners. The reason why a foreigner wants to learn your language is as important as your approach towards him/her and your effort to make the lesson fun and interesting in order to ensure that students do not become uninterested in the course. In this regard, the role of the lecturer is primary. The behaviors and approach of the lecturer towards students affect the interest of foreign students in Turkish either in a positive or negative way. " (Yılmaz \& Buzlukluoğlu Arslan,2014, p. 1185). According to Çiftçi (2011, p. 339), no matter which subject area is concerned, no matter which tools are used in the course, none of them is as effective as the teacher factor in achieving the learning outcomes. On the importance of the approach of the teacher, Soodak \& Podell (1997) argue that the perception and belief of the lecturer towards the course directly affect students and influence the acquired behavior or attitude of students towards the course and learning. Kara (2010) point to that some games played by the foreign students learning Turkish in the courses of writing, speaking, comprehension and grammar enabled them to learn Turkish faster and easier, to enjoy the course they willingly participate in and to ensure more permanent learning. The greatest contribution of this to teaching Turkish as a foreign language is that the feelings of fear and anxiety, which are the main obstacles in student dimension, are relieved through the provision of authentic and natural learning environments.

The other problem in teaching Turkish as a foreign language to the Syrian students regarding the Syrian students are discipline problems and violence. These students fled from the war in Syria and they are likely to have lost one or more of their close or distant relatives during the war. This may be the underlying reason for discipline problems and violence. Further, the lack of a holiday break for the Syrian students is an important problem. To improve in academia, the Syrian students attend the courses in the institutions and as these institutions follow a double shift schooling, the students also participate in the courses at the weekends. For example, Remedial Education Program (IYEP), first implemented by the Ministry of National Education in the 2018-2019 Academic Year, is intended to enable the $3^{\text {rd }}$ $4^{\text {th }}$ grade students, who attended the courses of Turkish and mathematics in the previous academic years for numerous reasons and failed to achieve the outcomes specified in the IYEP at the desired level, to achieve these outcomes. Psychosocial support is of great importance in adapting asylum seekers, immigrants and children under temporary protection, who are expected to constitute the majority of the target group in the program, into the educational system like their peers. Thus, psychosocial support was presented as an individual field in the program, along with the disciplines of Turkish and Mathematics, and integrated into these two disciplines. In the case that the institution follows a double shift schooling, the teaching activities to be performed within the framework of this project are included in the weekend schedule and students come to school seven days a week.

There are some problems regarding the learning environment in teaching Turkish as a foreign language to the Syrian children. Foremost among them is the insufficient number of classrooms. Most Turkish instructors do not have a dedicated class for language teaching. The instructors teach in whichever classroom is available. One of the most common problems is the lack of materials. The following course books are generally used for teaching Turkish as a foreign language to foreigners: Yunus Emre Enstitüsü Yedi İklim Türkçe Öğretim Seti et at the A1, A2, B1, B2, C1 levels by Yunus Emre Institute, Yeni Hitit Yabancılar için Türkçe Öğretim Seti 1-2, Yabancılar için Türkçe 1-2 by Gazi 
TÖMER. Yet, many students and instructors lack materials. There are certain problems regarding the lack of classroom equipment as well. Overcrowded classrooms as well as cleaning, heating and cooling problems are also notable.

There are some problems regarding the parents in teaching Turkish as a foreign language to the Syrian children. The major problem is parental indifference. Gözübüyük and Tamer (2017) report that parents are indifferent. The Syrian parents are indifferent and uninterested in making cooperation about their children's education. The lack of communication and parental behaviors that prevent the students from learning are also notable among these problems. Levent and Çayak (2017), in their study, put forward that the most common problem they encounter in regard to the Syrian students both during their enrolment in the school and teaching is communication. The parents did not want their children to speak Turkish and exhibited behaviors to prevent them from speaking Turkish, which may be considered as an effort to maintain their cultural identities.

Hattie (2009), in his synthesis of more than 800 meta-analyses on the factors that affect learning success, reveals that technology has a positive, albeit not strong, impact on learning success. The Turkish instructors were also asked whether they used instructional technologies in teaching Turkish as a foreign language to the Syrian children; a total of 15 participants out of 25 reflected that they use or sometimes use these technologies, and 9 participants stated that they do not use these technologies. It is thus notable that the number of the participants who do not use instructional technologies is substantial.

As for the effectiveness of the certification program for teaching Turkish as a foreign language created by TÖMER, the opinions of the participants were grouped based on three options: it was useful, it was somewhat useful and it was not useful. For the effectiveness of the program in determining outcomes, 12 participants $(63.16 \%)$ reflected that it was helpful or somewhat helpful whilst 7 participants $(36.48 \%$ ) reported that it was not helpful. For the effectiveness of the program in organizing and presenting the content, 12 participants $(70.59 \%)$ reflected that it was helpful or somewhat helpful whilst 5 participants $(29.41 \%)$ reported that it was not helpful. Also, for the effectiveness in using teaching methods and techniques, 10 participants (52.63\%) reflected that it was helpful or somewhat helpful whilst 9 participants (47.37\%) reported that it was not helpful. As put forth by Demirel (1999), the issue in teaching a foreign language is essentially about methods and the success in language teaching mostly depends on the methods used. According to Iş1k (2008, p. 23), the most critical deficit in foreign language education system is methodological errors. It has been found that most of the Turkish instructors agreed on the items referencing to grammar-translation methods and auditory-linguistic methods and adopted a perspective embracing these methods (Öztürk, 2018). Lastly, for the effectiveness in measurement and evaluation, 11 participants $(64.71 \%)$ reflected that it was helpful or somewhat helpful whilst 6 participants $(35.29 \%)$ reported that it was not helpful. These findings indicate that the certification program was not helpful at the desired level in the dimension of using teaching methods and techniques for the Turkish instructors teaching Turkish as a foreign language.

\section{Conclusions}

In regard to the four basic language skills, the study concludes that there are some problems in the reading skills, including pronunciation and confusion of vowels, differences in alphabets (reading backwards/reading like English), lack of reading comprehension, reading slowly and irrelevantly, inability to recognize letters and to combine letters and syllables. Regarding the writing skill, the problems such as forgetting vowels in words and mistaking some vowels for others (e.g. o-ö and u-ü), and writing backwards, using imitation and disobeying the rules to write, are present. As for the listening skills, loss of motivation due to lack of comprehension and poor listening skills are notable. In relation 
to the speaking skills, the problems such as not needing to speak Turkish, mispronunciations, speaking without using tenses and suffixes, difficulties due to Turkish sentence structure and poor vocabulary are present.

The problems faced by the Turkish instructors regarding the administration are indifferent and adverse behaviors exhibited by the administration and uncertain work hours and lack of a schedule. Among the problems faced by the Turkish instructors regarding the teachers and other instructors in the administration, there are negative behaviors of the teachers in the institution and lack of cooperation, negative behaviors of the instructors and problems regarding merit. The problems with respect to the Syrian students are lack of interest, discipline problems and violence, and lack of a holiday break. The problems regarding the parents are parental indifference, the lack of communication and parental behaviors that prevent the students from learning. Among the problems regarding the learning environment, there are insufficient number of classrooms, lack of materials, lack of classroom equipment, overcrowded classrooms, and cleaning, heating and cooling problems.

The findings on the use of instructional technologies among the Turkish instructors show that although most of them expressed that they use or sometimes use instructional technologies, some instructors do not use these technologies. It is also notable that according to the participants, the certification program for teaching Turkish as a foreign language was helpful in determining outcomes, presenting and organizing the content, evaluation and measurement, but the program was not considered helpful at the desired level in using teaching methods and techniques.

\subsection{Suggestions}

- In regard to the four basic language skills, more focus should be placed on teaching vowels and constants, which are often confused by students; dictation activities should be used to teach them,

- The activities jointly performed by Syrian students and Turkish students should be diversified; and Syrian students should feel the need to speak Turkish,

- There should be activities intended to improve the four basic language skills outside the classroom,

- Both visual and auditory stimuli should be presented together in courses. These stimuli should be presented not only in computers or interactive whiteboards but also at concerts, theaters, live events, etc,

- The most common subjects in everyday life should be primarily considered in the selection of the texts used for listening activities; the levels and areas of interests should be taken into consideration,

- Considering their levels and interests, Syrian students should be informed of listening types, methods, techniques and strategies and be given with opportunities to apply them,

- More attention should be placed on writing letters in the right direction; students in small groups should be provided with instant feedbacks in writing activities,

- The work hours of the Turkish instructors should be well organized by a commission with broad participation at the institution; no overtime work should be assigned to the Turkish instructors,

- Administrators, teachers and instructors at the institution share the same responsibility for ensuring that Syrian students are provided with Turkish education. For that reason, measures and activities should be organized by the school administration to improve the cooperation between these shareholders, 
- Activities should be organized to increase the interest and motivation of the Syrian students. Research should be conducted to understand the reasons for the loss of interest and motivation among the Syrian students, and an action plan should be prepared according to the findings,

- School guidance services at institutions should be effectively consulted to prevent discipline problems and violence caused by the Syrian students. If necessary, professional development programs should be created to help these personnel deal with the problems of the refugee children and be solution-oriented towards these problems,

- While providing additional education services to the Syrian students, their needs to take a break or to rest should be taken into consideration,

- There should be dedicated classrooms for the Turkish education of the Syrian students and necessary equipment should be provided,

- Materials appropriate to their interests and levels should be designed for the education of the Syrian students,

- The Syrian students should be homogeneously distributed to the institutions in the provinces and districts they reside in,

- Family trainings should be organized for the parents of the Syrian students with the help of interpreters and equipped instructors. Adult trainings should be also organized in the institutions,

- Technology support should be provided to the institutions with the Syrian students and it should be ensured that instructors use these technologies. Teachers who have difficulty in using interactive whiteboards should attend short-term in-service trainings,

- E-content compatible with interactive boards should be prepared for teaching Turkish to the Syrian students,

- The certification program should be offered regularly throughout the year and the educators involved in this program should be experienced in their fields; those who are specialized in teaching Turkish particularly to the Syrian students as a foreign language should be involved in the program,

- Activities should be organized to help Turkish instructors improve students' writing skills by taking into consideration their interests, needs and levels of Turkish within the framework of their levels of proficiency; the certification program should include examples of achievements of experienced people in the field,

The section of foreign language teaching methods and techniques in the certification program for teaching Turkish as a foreign language should be particularly reviewed and revised according to the requests from and needs of the instructors.

\section{Ethics Committee Approval}

The authors confirm that this study does not need ethics committee approval. (Date of Confirmation: 12.03.2020) 


\section{References}

Akar, H. (2017). Durum çalışması. eğitimde nitel araştırma desenleri (ed. Ahmet SABAN-Ali ERSOY). Ankara: Anı Yayınc1l1k, 140-177.

Aydın, T. (2007). Arapça ve Türkçede cümle yapısl, yabancılara Arapça cümle öğretimi -karşıtsal çözümleme- Unpublished doctoral dissertation, Ankara Gazi Üniversitesi.

Aydın, G. (2009). Zihin haritalama tekniğinin dinleneni anlamaya etkisi. Atatürk Üniversitesi Sosyal Bilimler Enstitüsü Dergisi, 14(2), 47-62.

Aykırı, K. (2017). Sınıf öğretmenlerinin sınıflarındaki Suriyeli öğrencilerin eğitim durumlarına ilişkin görüşleri. Turkish Journal of Primary Education, 2, 44-56.

Bağ Gözükara G., Karabulut E., \& Alpar R.(2010). 2x2 tablolarda gözlemciler/gözlemler arası uyumun değerlendirilmesi. Hacettepe Diş Hekimliği Fakültesi Dergisi. 34(1-2), 46-52.

Bilgegil, K. (2009). Türkçe dilbilgisi. Erzurum: Salkım Söğüt Yayınları.

Buran, A.,Yüksel Çak, B. (2012). Türkiye'de diller ve etnik gruplar. Ankara: Akçă̆ Yayınları.

Buzan, T. (2006). Aklını en iyi şekilde kullan. (Çev. Banu Ergüder). İstanbul: Arion Yayınevi.

Büyükikiz, K.K., \& Hasırc1, S. (2013). Yabancı dil olarak Türkçenin öğretiminde sözcük öğretimi üzerine bir değerlendirme. Mustafa Kemal Üniversitesi Sosyal BilimlerEnstitüsü Dergisi, 10(21), 145-155.

Büyükikiz, K.K.(2014). Türkçeyi yabancı dil olarak öğrenen C1 düzeyindeki öğrencilerin dinleme becerisine ilişkin görüşleri. Gaziantep University Journal of Social Sciences, 13(3), 793-805.

Büyükikiz, K. K., \& Çangal, Ö. (2016). Suriyeli misafir öğrencilere Türkçe öğretimi projesi üzerine bir değerlendirme. Uluslararası Türkçe Edebiyat Kültür Eğitim Dergisi, 5(3), 1414-1430.

Büyüköztürk, Ş., Çakmak, E.K., Akgün, Ö.E., Karadeniz, Ş. \& Demirel, F. (2014). Bilimsel araştırma yöntemleri. Ankara: Pegem A Yayıncılık.

Bölükbaş, F.(2011). Arap öğrencilerin Türkçe yazılı anlatım becerilerinin değerlendirilmesi. International Periodical For The Languages, Literature and History of Turkish or Turkic, 6(3), 1357-1367.

Bryt T, Bishop, J., \& Carlin, J.B.(1993). Bias, prevalence and kappa. J Clin Epidemiol, 46, 423-429.

Cemiloğlu, M. (2004). İlköğretim okullarında Türkçe öğretimi. Bursa: Alfa Akademi.

Cihangir, Z. (2004). Kişilerarası İletişimde Dinleme Becerisi. Ankara: Nobel Kitap.

Cohen, J.(1960). A coefficient of agreement for nominal scales, Educational and Psychological Measurement, 20, 37-46.

Common European Framework of Reference For Languages: Learning, Teaching, Assessment, Language Policy Unit, Strasbourg, 2001

Coşkun, E. (2007). Yazma becerisi. A. Kırkkılıç, H. Akyol (Ed.), İlköğretimde Türkçe öğretimi. Ankara: Pegem A.

Creswell, J.W., \& Miller, D.L. (2000). Determining validity in qualitative inquiry: Theory into Practise, 39(3), 124-130.

Çiftçi, M. (2011). Türkçe öğretmeni yetiştirme programı sorunu. Turkish Studies, 6(1), 399-405. 
Demir, T. (2004). Türkçe Dilbilgisi. Ankara: KurmayYayınları.

Demirci, M. (2015). B1 seviyesinde Türkçe öğrenen Suriyeli öğrencilerin sesli okuma becerisiyle ilgili tespitler. Turkish Studies.10(7), 333-358.

Demirel, Ö. (1999). Illköğretim Okullarında Türkçe Öğretimi. İstanbul: MEB Basımevi.

Demirel, Ö. (2004). Yabancı dil ögrretimi, dil pasaportu, dil biyografisi, dil dosyası. Ankara: PegemYayıncilik.

Dönmez M. İ., \& Paksoy, S. (2015). Türkiye’de öğrenim gören Suriyeli öğrencilerin Türkçe öğrenmede karşılaştıkları sorunlar üzerine bir araştırma: Kilis 7 Aralık Üniversitesi örneği. International Journal of Languages Education and Teaching UDES 201., 1907-1919.

Ergin, M. (1998). Türk dil bilgisi. İstanbul: Bayrak Yayınevi.

Erdem, C. (2017). Sınıfında mülteci öğrenci bulunan sınıf öğretmenlerinin yaşadıkları öğretimsel sorunlar ve çözüme dair önerileri. Medeniyet Eğitim Araştırmaları Dergisi. 1(1), 26-42.

Eyüp, B., Arslan, N., \& Cevher, T. Y. (2017). Mültecilere 'Türkçenin yabancı dil olarak öğretilmesine yönelik uyum kursuna katılan öğreticilerin kurs hakkındaki görüşleri ve hazırbulunuşluk durumları. International Journal of Languages' Education and Teaching, 5(4), 174-200.

Fleiss J.L.(1971). Measuring nominal scale agreement among many raters. Psychological Bulletin, 7, 378-382.

Glaser, B., \& Strauss, A.L. (1967). Discovery of grounded theory: Strategies for qualitative research. Chicago: Aldine.

Gordis L.(2014). Epidemiology Fifth Edition, Elsevier Saunders Inc.107-10

Göğüş, B. (1978). Türkçe ve yazın ögrretimi. Ankara: Kadığlu Matbaası.

Gözübüyük Tamer, M. (2017). Geçici koruma kapsamındaki Suriyeli çocukların Trabzon devlet okullarındaki durumu. GöçDergisi.4(1),119-152.

Gürler, M.(2019). Yabancı dil olarak türkçe öğrenen suriyeli öğrencilerin yazılı anlatımlarında hata çözümlemesi. ( master's thesis ). Erişim adresi: http://www.openaccess.hacettepe.edu.tr:8080/xmlui/handle/11655/8141

Hattie, J. (2009). Visible learning: A synthesis of over 800 meta-analyses relating to achievement. London and New York: Routledge. https://tegm.meb.gov.tr/meb_iys_dosyalar/2018_09/13134503_YYEP_Uygulama_KYlavuzu.pdf

Işık, A. (2008). Yabancı dil eğitimimizdeki yanlışlar nereden kaynaklanıyor? Journal of Language and Linguistic Studies, 4(2), 15-26.

İşler, E., \& Yıldız, M. (2002). Arapça çeviri kılavuzu, Ankara: Gündüz EğitimveYayıncılık.

Kara, M. (2010). Gazi üniversitesi tömer öğrencilerinin Türkçe öğrenirken karşılaştıkları sorunlar ve bunların çözümüne yönelik öneriler. Türk Eğitim Bilimleri Dergisi, 8(3). 661-696.

Karaağaç, G. (2013). Türkçenin dil bilgisi. Ankara: Akçağ Yayınları.

Karakuş, İ. (2000). Türkçe Türk dili ve edebiyatı öğretimi. Ankara: Sistem Ofset Yayınları.

Kavcar, C., Oğuzkan, F. \& Sever, S. (1999). Türkçe öğretimi. Ankara: EnginYayınları.

Kilıç, S.(2015). Kappa testi. Journal of Mood Disorders 2015, 5(3): 142-144.doi: 10.5455/jmood.20150920115439 
Kundel, H.L., \& Polansky, M.(2003).Measurement of observer agreement. Radiology 228: 303-308.

Landis J.R., \& Koch, G.G.(1977). The measurement of observer agreement for categorical data. Biometrics.33:159-74.

Levent, F., \& Çayak, S. (2017). Türkiye'deki Suriyeli öğrencilerin eğitimine yönelik okul yöneticilerinin görüşleri. Hasan Ali Yücel Eğitim Fakültesi Dergisi, 14-1(27), 21-46.

Lundsteen, S. W. (1979). Listening: Its impact on reading and the other language arts. Urbana IL: National Counsel of Teachers of English.

Makodia, V. V. (2009). Role of body language in communication. Jaipur, India: Paradise.

McMillan, J.H. (2000). Educational research: Fundamentals for the consumer (3rd edition). New

York: Longman.

Moralı, G. (2018). Suriyeli mülteci çocuklara Türkçenin yabancı dil olarak öğretiminde karşılaşılan sorunlar. OPUS -Uluslararası Toplum Araştırmalart Dergisi, 8(15), 1426-1449.doi: 10.26466/opus. 443945

Özbay, M. (2007). Türkçe özel ögrretim yöntemleri II. Ankara: Öncü Kitap.

Özbay, M.(2012). Anlama teknikleri II dinleme eğitimi Ankara: Öncü Kitap.

Özkan, T., Demir K., \& Özdemir A. (2017). Yabancı dil olarak Türkçe öğreticileri için yenilikçi ve uygulanabilir teknolojik yöntem önerisi. The Journal of International Lingual, Social and Educational Sciences, 3(2).

Öztürk, B.(2018). Yabancı dil olarak Türkçe öğretiminde öğreticilerin yöntemlere yönelik bakış açısı ve farkındalığ1. Tarih Okulu Dergisi, 33, 969-996. doi: http://dx.doi.org/10.14225/Joh1208

Robertson, A. K. (2008). Etkili dinleme, (Çev. E. SabriYarmalı), İstanbul: Hayat Yayınları.

Saban, A., \& Ersoy, A. (Ed.). (2017). Eğitimde nitel araştırma desenleri. (Extended 2nd edition) Ankara: Anı Yayıncılık.

Sarıtaş, E., Şahin, Ü., \& Çatalbaş, G. (2016). İlkokullarda yabancı uyruklu öğrencilerle karşıllaşılan sorunlar. Pamukkale Üniversitesi Sosyal Bilimler EnstitüsüDergisi, 25(1), 208-229.

Sim, J., \& Wright, C.C.(2005). The kappa statistic in reliability studies: use, interpretation, and sample size requirements. Physical Therapy. 85:257-68.

Soodak, L. C., \& Podell, D. M. (1997). Efficacy and experience: perceptions of efficacy among preservice and practicing teachers. Journal of Research and Development in Education, 30, 214 221.

Şahin, A. (Ed.).(2018). Yabancı dil olarak Türkçe öğretimi kuramlar, yaklaşımlar, etkinlikler.Ankara: Pegem AkademiYayınc1lık.

Ünalan, Ş. (2006).Türkçe öğretimi (3rd edition), Nobel Yayın Dağıtım, Ankara.

Yalçın, A. (2002). Türkçe ögretim yöntemleri. Ankara: Akçağ.

Yıldırım, A., \& Şimşek, H. (2013). Sosyal Bilimlerde Nitel Araştırma Yöntemleri. (9th edition). Ankara: Seçkin Yayıncılık.

Yılmaz, F., \& Buzlukluoğlu Arslan, S. (2014). ÇOMÜ Tömer’ de Türkçe öğrenen yabancı öğrencilerin motivasyon kaynakları ve sorunlar1. ANKARA-TURKEY: Turkish Studies International Periodical For The Languages, Literature and History of Turkish or Turkic Volume 9/6. 1185. 
Yin, R.K. (1984). Case study research: Design and methods (1st edition). Beverly Hills: Sage.

Yin, R.K. (2014). Case study research: Designs and methods (5th edition). Thousand Oaks, CA: Sage

Yüce, S. (2005). İletişim ve dil: yöntemler, Avrupa dil portföyü Türkçenin yabancı dil olarak öğretimi. Journal of Language and Linguistic Studies, 1(1), April 2005.

\title{
Suriyeli çocuklara yabancı dil olarak Türkçe öğreten öğreticilerin karşılaştıkları sorunlar ve katıldıkları yabancı dil olarak Türkçe öğretimi sertifika program'ına yönelik görüşleri
}

\begin{abstract}
$\ddot{O} \mathbf{z}$
$\mathrm{Bu}$ araştırmanın amacı, PICTES projesi kapsamında ilköğretim kurumlarında ve kamplarda görev yapan Türkçe öğreticilerinin, Suriyeli öğrencilere yabancı dil olarak Türkçe öğretiminde karşılaştıkları sorunları tespit etmek ve TÖMER tarafindan düzenlenen, yabancı dil olarak Türkçe öğretimi sertifika programına yönelik öğretici görüşlerini belirlemektir. Bu araştırma nitel bir araştırma modeli olan durum çalışması olup, çalışma grubu amaçlı örnekleme yöntemiyle belirlenmiş, Mersin ve Adana illerinde görev yapan 25 Türkçe öğreticisidir. Veriler kişisel bilgi formu ve görüşme formu aracılığı ile toplanmıştır. Verilerin içerik analizi yapılmış ve verilerin analizinde QDA (Qualitative Data Analysis) Miner Lite programı kullanılmıştır. Veri analizi sonucunda, 14 tema ve bu temaların altında toplanmış 37 kod bulunmuştur. $\mathrm{Bu}$ araştırma kapsamında ulaşılan sonuçlar alanyazındaki çalışmalarla büyük ölçüde benzerlik gösterdiği, öğreticilerin çoğunun öğretim teknolojilerini kullanmadığı ve TÖMER tarafından düzenlenen sertifika programının ise öğreticilere öğretim yöntem ve teknikleri kullanmada istenilen katkıyı sağlamadığı görülmüştür.
\end{abstract}

Anahtar sözcükler: Yabancı dil olarak Türkçe öğretimi; Suriyeli çocuklar; öğretim teknolojileri; tömer; pictes

\section{AUTHOR BIODATA}

Ufuk Özkale Republic of Turkey Ministry of National Education has been working as a teacher since 2008. He received his master's degree from Mersin University in the field of Educational Sciences-Curriculum and Instruction. He continues his doctoral studies in the same field.

Prof. Dr. Tuğba Yanpar Yelken was born in Mersin/Turkey in 1970. She received her undergraduate degree at Hacettepe University Faculty of Education in 1990. She started to work as research assistant and received her Ph.D. degree in 1997 at Hacettepe University, Department of Educational Sciences. In 2009, she became professor. She has carried out national and international academic studies on education from primary to higher education, instructional methods and techniques, instructional technologies and material design, teacher training, lifelong learning and higher education quality assurance. She currently has the role as head of the department of Educational Sciences-Curriculum and Instruction. She is a member of Turkish Higher Education Quality Council. 